Review

\title{
Bio-Catalysis and Biomedical Perspectives of Magnetic Nanoparticles as Versatile Carriers
}

\author{
Muhammad Bilal ${ }^{1, *}$ (D) Shahid Mehmood ${ }^{2}$, Tahir Rasheed ${ }^{3}$ and Hafiz M. N. Iqbal ${ }^{4, *(\mathbb{D})}$ \\ 1 School of Life Science and Food Engineering, Huaiyin Institute of Technology, Huaian 223003, China \\ 2 Bio-X Institute, Key Laboratory for the Genetics of Developmental and Neuropsychiatric Disorders (Ministry \\ of Education), Shanghai Jiao Tong University, Shanghai 200030, China \\ 3 School of Chemistry \& Chemical Engineering, State Key Laboratory of Metal Matrix Composites, \\ Shanghai Jiao Tong University, Shanghai 200240, China \\ 4 Tecnologico de Monterrey, School of Engineering and Sciences, Campus Monterrey, \\ Ave. Eugenio Garza Sada 2501, Monterrey, N.L. CP 64849, Mexico \\ * Correspondence: bilaluaf@hotmail.com (M.B.); hafiz.iqbal@itesm.mx or hafiz.iqbal@tec.mx (H.M.N.I.); \\ Tel.: +52-81-8358-2000 (ext. 5679) (H.M.N.I.)
}

Received: 9 May 2019; Accepted: 27 June 2019; Published: 2 July 2019

\begin{abstract}
In recent years, magnetic nanoparticles (MNPs) have gained increasing attention as versatile carriers because of their unique magnetic properties, biocatalytic functionalities, and capabilities to work at the cellular and molecular level of biological interactions. Moreover, owing to their exceptional functional properties, such as large surface area, large surface-to-volume ratio, and mobility and high mass transference, MNPs have been employed in several applications in different sectors such as supporting matrices for enzymes immobilization and controlled release of drugs in biomedicine. Unlike non-magnetic carriers, MNPs can be easily separated and recovered using an external magnetic field. In addition to their biocompatible microenvironment, the application of MNPs represents a remarkable green chemistry approach. Herein, we focused on state-of-the-art two majorly studied perspectives of MNPs as versatile carriers for (1) matrices for enzymes immobilization, and (2) matrices for controlled drug delivery. Specifically, from the applied perspectives of magnetic nanoparticles, a series of different applications with suitable examples are discussed in detail. The second half is focused on different metal-based magnetic nanoparticles and their exploitation for biomedical purposes.
\end{abstract}

Keywords: green chemistry; magnetic nanoparticles; enzyme immobilization; controlled drug delivery; supporting materials

\section{Introduction}

Green or sustainable chemistry is the utilization of a set of principles that diminishes the use of toxic substances in the design, manufacture, and application of the chemical product. This fact encouraged the researchers and scientific community to discover simple and effective methods for the separation of homogenous catalysts from the reaction mixture and their subsequent recycling. The use of magnetic nanoparticles (MNPs) as efficient support materials for biocatalyst immobilization has become a theme of considerable interest. A range of attractive properties including high surface area, large surface-to-volume ratio, facile separation using external magnetic fields, and high mass transfer make MNPs ideal candidate for diverse biomedical applications [1,2]. MNPs exhibit their highest performance at sizes typical ranges from 10 to $20 \mathrm{~nm}$ due to the occurrence of the superparamagnetism property [3]. Recently, MNPs find potential use in catalysis including nanostructured material-assisted biocatalysts immobilization, biomedicine, target-oriented drug delivery, magnetic resonance imaging 
(MRI), microfluidics, nanofluids, optical filters, data storage, and environmental remediation [4]. Herein, we focused on state-of-the-art two majorly studied applications of MNPs as versatile carriers for (1) matrices for enzymes immobilization, and (2) matrices for controlled drug delivery. Following the introduction, the formation and stabilization of magnetic nanoparticles are briefly discussed. From the applied perspectives of magnetic nanoparticles, a series of different applications with suitable examples are discussed in detail. The second half is focused on different metal-based magnetic nanoparticles and their exploitation for biomedical purposes.

\section{Magnetic Nanoparticles: Formation and Stabilization}

MNPs properties are firmly dependent on formation and construction method. For the synthesis of high-quality nanoparticles, particle-size distribution, particle size, symmetry, and crystallization have been governed with the help of advance colloidal system [5]. All these features of MNPs provide mono-dispersity and homogeneity in the target system. Sometimes, MNP required a stabilizing agent in a competitive environment to avoid from agglomeration, for example, in dipolar conditions, these particles face high surface-to-volume ratio [6]. Currently, there is a variety of nanomaterials available commercially [7]. Therefore, it reduces the effort of nanoparticle researchers and increases productivity. In spite of these facts, more work and experiments are needed to customize, develop, and synthesize purpose-built nanoparticles.

From a material chemistry perspective, the material used for the development of magnetic entity can be originated or constructed from iron (oxides), nickels, and cobalt. Sometimes elements such as strontium, zinc, barium, and zinc can also be conjugated with metals. Generally, MNPs belongs to the nanoalloy and metallic nanomaterials that are coated with specific kind of molecules $[8,9]$. These modifications make it target specific, enhance the stability, and improve the physiochemical properties (corrosion, oxidation, agglomeration, and toxicity) of nanoparticles [10,11]. Lastly, customized modification of MNPs both core and surface depend upon the system to be applied [12]. For example, agglomeration of MNPs with avidin-biotin (bifunctional linkers) increase the stability up to several months [13], oligos-based modification was used for DNA detection [14,15], modification with iron oxide or ferrites is the potential application for X-ray computed tomography or MRI [16]. Similarly, MNPs were coated with other conjugated molecules such as liposomes, micelles, polymeric coating, and core-shell structures (Figure 1) [17].
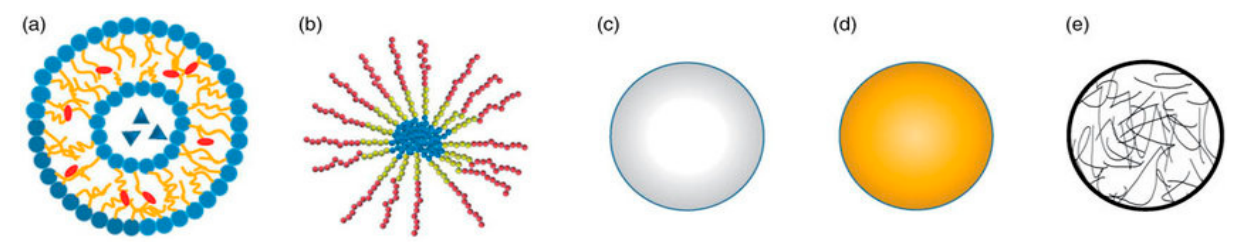

Figure 1. Representative structures of various NPs for drug delivery. (a) Liposomes, (b) polymeric micelles, (c) polymeric nanoparticle, (d) gold nanoparticle, and (e) nanogel. Reprinted from Wang et al. [17], an open-access article distributed under the terms of the Creative Commons Attribution License (http://creativecommons.org/licenses/by/4.0/). Copyright (2018) the author(s). Published by Informa UK Limited, London, UK, trading as Taylor \& Francis Group.

\section{Applications of Magnetic Nanoparticles}

\subsection{Bio-Catalysis Perspectives of Magnetic Nanoparticles}

Over the past two decades, a wide variety of nano-carriers has been fabricated and applied as enzymes immobilization supports for diverse applications (Table 1). Among these support materials, MNPs have received substantial attention as versatile carriers, because of their unique physicochemical and magnetic properties, biodegradability, biocompatibility, low cost, and tailor-made surface chemistry. Also, MNPs allow facile, rapid, and efficient biocatalyst separation from the reaction media by using an external magnet [18]. 
Table 1. Summary of magnetic nanomaterials as versatile carriers for enzymes immobilization, and their applications

\begin{tabular}{|c|c|c|c|c|}
\hline Magnetic Carrier & Name of Enzyme & $\begin{array}{c}\text { Immobilization } \\
\text { Technique }\end{array}$ & Improved Properties and Application of Immobilized Enzymes & References \\
\hline Magnetic graphene oxide & $\begin{array}{l}\text { Chloroperoxidase/glucose } \\
\text { oxidase }\end{array}$ & Physical adsorption & $\begin{array}{l}\text { Excellent catalytic efficiency, operational durability, and recyclability. } \\
\text { Immobilized biocatalyst showed far greater thermal stability compared with the native enzyme. } \\
\text { It presented an application in decolorization and degradation of many synthetic dyes from industrial wastewater. }\end{array}$ & [19] \\
\hline $\begin{array}{l}\text { hydrophobic virus-like } \\
\text { organosilica nanoparticles }\end{array}$ & Candida antarctica lipase B & Covalent attachment & $\begin{array}{l}\text { Improved } \mathrm{pH} \text { and thermal resistance High tolerance to organic solvents and long-term storage stability. } \\
\text { Efficient esterification reaction of levulinic acid retaining } 75.7 \% \text { of the levulinic acid transformation after } 9 \text { continuous } \\
\text { biocatalytic cycles. }\end{array}$ & [20] \\
\hline $\begin{array}{l}\text { Chitosan-cross-linked } \\
\text { magnetic nanoparticles }\end{array}$ & Candida antarctica lipase B & Covalent attachment & $\begin{array}{l}\text { Superior separation and biocatalytic properties. } \\
\text { Excellent storage stability and reusability. } \\
\text { Production of bio-based photocurable oligo-esters by the ring opening esterification of polyols and itaconic anhydride. }\end{array}$ & [21] \\
\hline $\begin{array}{l}\text { Barium ferrite } \\
\text { magnetic microparticles }\end{array}$ & Alcohol oxidase & Covalent attachment & $\begin{array}{l}\text { Enhanced thermostability retaining }>65 \% \text { of the original activity at } 45^{\circ} \mathrm{C} \text { for } 24 \mathrm{~h} \text {. } \\
\text { Good catalytic efficacy for oxidizing ethanol and methanol compared with the free enzyme. Recyclability for at three } \\
\text { successive batches with } 70 \% \text { activity retention. }\end{array}$ & [22] \\
\hline $\begin{array}{l}\text { Glutathione-coated gold } \\
\text { magnetic nanoparticles }\end{array}$ & Inulinase & Covalent binding & $\begin{array}{l}\text { Enhanced storage and reusability stability. } \\
\text { Immobilized biocatalyst preserved about } 78 \% \text { of its original activity after } 10 \text { repeated cycles. } \\
\text { Improved enzyme performance at acidic } \mathrm{pHs}(3.0 \text { and } 4.0) \text { and high temperature up to } 80^{\circ} \mathrm{C} \text {. Complete hydrolysis of inulin } \\
\text { to fructose and glucose. }\end{array}$ & [23] \\
\hline $\begin{array}{l}\text { Ionic liquid-modified magnetic } \\
\text { chitosan composites }\end{array}$ & Lipase & Adsorption & $\begin{array}{l}\text { Elevated catalytic activity (6.72-fold) as compared to the free enzyme } \\
\text { Enhanced thermal stability and reusability retaining } 92.1 \% \text { of residual activity after } 10 \text { cycles of reuse. }\end{array}$ & [24] \\
\hline $\begin{array}{l}\mathrm{Fe}_{3} \mathrm{O}_{4} \text { magnetic nanoparticles } \\
\text { functionalized with wheat } \\
\text { gluten hydrolysates }\end{array}$ & Inulinase & Covalent binding & $\begin{array}{l}\text { High activity over a broader } \mathrm{pH} \text { and temperature ranges, and also exhibited pronounced storage and thermal stability. } \\
\text { The inulinase showed } 12.3 \text { folds rise in enzyme half-life value at } 75{ }^{\circ} \mathrm{C} \\
\text { Potential recyclability retaining } 70 \% \text { of its preliminary catalytic activity after } 12 \text { continuous inulin hydrolysis cycles. }\end{array}$ & [25] \\
\hline $\begin{array}{l}\text { FunctionalizedAPTMS-magnetite } \\
\text { nanoparticles }\end{array}$ & Cellulase and pectinase & Covalent immobilization & $\begin{array}{l}\text { Improved characteristics such as high activities recovery, enhanced temperature stability (2.39-times greater than that to the } \\
\text { free enzyme), and reusability for up to } 8 \text { continuous cycles in grape juice clarification. }\end{array}$ & [26] \\
\hline $\begin{array}{l}\text { Chitosan-montmorillonite } \\
\text { nanocomposite beads }\end{array}$ & $\alpha$-amylase & Cross-linking & $\begin{array}{l}\text { High enzyme activity and stability at varying } \mathrm{pH} \text { and temperature conditions than the free enzyme. } \\
\text { Retention of about } 53 \% \text { enzyme relative activity after recycling } 5 \text { times }\end{array}$ & [27] \\
\hline $\begin{array}{l}\text { Chitosan magnetic } \\
\text { nanoparticles }\end{array}$ & Pectinase & Cross-linking & $\begin{array}{l}\text { Superior thermal stability than the soluble form of the enzyme. } \\
\text { High stabilization retaining } 87 \% \text { of original activity after seven repeated cycles. } \\
\text { Excellent durability. } \\
\text { Potential apple juice clarification with up to } 74 \% \text { turbidity reduction after } 2.5 \mathrm{~h} \text { of treatment. }\end{array}$ & [28] \\
\hline $\begin{array}{l}\text { Amino-functionalized magnetic } \\
\text { nanoparticle }\end{array}$ & $\begin{array}{l}\alpha \text {-amylase, cellulose, } \\
\text { and pectinase }\end{array}$ & Cross-linking & $\begin{array}{l}\text { Increased } \mathrm{pH} \text { and thermal stability Encouraging enzyme reusability preserving up to } 75 \% \text { of activity after } 8 \text { reuse cycles. } \\
\text { Clarification of fruit juices. } \\
\text { Significant decrease in turbidity. }\end{array}$ & [29] \\
\hline $\begin{array}{l}\text { Magnetic cornstarch } \\
\text { microspheres }\end{array}$ & Pectinase & Adsorption & $\begin{array}{l}\text { Improved } \mathrm{pH} \text { and thermal stability. } \\
\text { Good reusability and operability of the immobilized biocatalyst preserving } 60 \% \text { of its initial activity after } 8 \text { reuses in apple } \\
\text { juice processing. }\end{array}$ & [30] \\
\hline $\begin{array}{l}\text { Magnetic } \mathrm{Fe}_{3} \mathrm{O}_{4} @ \text { chitosan } \\
\text { nanoparticles }\end{array}$ & Lipase & Covalent immobilization & $\begin{array}{l}\text { Immobilized biocatalyst presented more than } 50 \% \text { and } 75 \% \text { residual activity in the } \mathrm{pH} \text { range } 7.0-11.0 \text {, and } 70{ }^{\circ} \mathrm{C} \text {. } \\
\text { Satisfactory reusability preserving } 70 \% \text { of its original activity after } 10 \text { repeated cycles. } \\
\text { More than } 50 \% \text { conversion of ascorbic acid was achieved when used for ascorbyl palmitate synthesis in tert-butanol at } 50^{\circ} \mathrm{C} \text {. }\end{array}$ & [31] \\
\hline
\end{tabular}

APTMS-3-aminopropyltrimethoxysilane. 


\subsection{Degradation of Dye Pollutants}

Different dyes including acid blue 45 , crystal violet, and orange $G$ have shown wider applications in paper, textile, food, and many other industries. However, these dyes and other dyes containing pollutants pose severe threats to human health and aquatic organisms [32]. Due to their high photolytic and chemical stability, these dye pollutants are resilient to classical chemical, physical, and biological treatment methods. Enzymes as biocatalysts can be employed both in free as well as immobilized forms in the treatment of dyes or dyes-harboring industrial wastewater. However, immobilized enzymes present the advantages of durable catalytic stability, easy separation, and recovery, and multiple recycling, which improve the performance and trim-down the overall cost of industrial bioprocess [33-38]. Immobilized enzymes can be developed by different chemical and physical methods, which affect biocatalytic properties of the resulting immobilized system, and hence their applications in explicit processes [39,40].

Reports have shown the fascinating efficiency of chloroperoxidase (CPO) in degrading an array of synthetic dyes. Nevertheless, the lack of durable functioning stability and difficulty in recycling $\mathrm{CPO}$ hampered its large-scale application in wastewater bioremediation. To overcome this issue, Gao and coworkers, (2019) co-immobilized CPO and glucose oxidase (GOx) on the surface of magnetic graphene oxide (MGO). The catalytic performance of MGO-GOx-CPO considerably enhanced $(96.6 \%)$ towards the degradation of orange $\mathrm{G}$ relative to MGO-GOx+MGO-CPO $(86.2 \%)$, presumably because of reduced mass transfer limitation between $\mathrm{CPO}$ and $\mathrm{H}_{2} \mathrm{O}_{2}$ produced from $\mathrm{GOx}$ molecules (Figure 2) [19]. Remarkably, MGO-GOx-CPO exhibited its maximum activity at a temperature above $40{ }^{\circ} \mathrm{C}$ compared with the optimal temperature of $35^{\circ} \mathrm{C}$ for the soluble biocatalyst. It also showed potential repetitive usability retaining $\sim 38.5 \%$ of initial activity after six dye-decolorization cycles demonstrating the possibility of co-immobilized $\mathrm{CPO}$ and GOx in environmental applications. A peroxidase enzyme isolated and purified from the textile wastewater was immobilized on glutaraldehyde-functionalized $\mathrm{Fe}_{3} \mathrm{O}_{4}$ MNPs. The MNPs-insolubilized enzyme showed remarkable stability towards a range of $\mathrm{pH}$ and temperature perturbations than to the free form of the enzyme. It retained complete catalytic activity following storage at $4{ }^{\circ} \mathrm{C}$ and $25^{\circ} \mathrm{C}$ for three months, and upon reusing for up to 100 repeated cycles. Moreover, the MNPs-assisted novel peroxidase was effectively used for the decolorization and degradation of industry wastewater containing direct green or reactive red azo dye pollutants in a prototype sequential lab-scale bioreactor [41]. In a recent study, Kashefi and coworkers [42] synthesized the magnetic graphene oxide (MGO) by integrating exclusive GO properties with the superparamagnetic characteristics of the $\mathrm{CuFe}_{2} \mathrm{O}_{4}$ nanoparticles. The amine group on MGO was functionalized chemically modified with 3-amino propyl trimethoxy silane and cross-linked activated with GLU. As-prepared functionalized MGO was utilized to covalently immobilize a laccase enzyme from genetically modified Aspergillus and exploited to degrade an azo dye Direct Red 23 using the response surface methodology. Results revealed that the immobilized nanobiocatalyst caused a maximum decolorization efficiency of $95.33 \%$ under the optimal conditions-i.e., $\mathrm{pH}$, dye concentration, and enzyme dosage of $4.23,19.60 \mathrm{mg} / \mathrm{L}$, and $290.23 \mathrm{mg} / \mathrm{L}$-respectively. In conclusion, it can be stated that the superparamagnetic nanomaterials-immobilized enzyme can potentially act as green and environmentally responsive nanobiocatalyst for efficient decolorization purposes [42].

\subsection{Fruit Juice Clarification}

In recent years, the development of new strategies for fruit juice clarification has gained a great interest in improving the quality of the juices. The turbid and cloudy appearance of the freshly prepared fruit juices resulting from the colloidal dispersion of pectin is one of the major issues in fruit juice processing [43]. Moreover, the presence of starch and other polysaccharides (i.e., cellulose and hemicellulose) tend to settle down during preservation resulting in haziness and poor-quality fruit juice [44]. Current employing microfiltration and ultrafiltration clarification technologies are restricted during the elimination of suspended pulp particles causing membrane fouling and reduce the membrane lifespan [45]. The use of immobilized enzymes has been substantially increased in 
fruit juice industry to circumvent turbidity, cloudiness, and undesirable haziness accompanied by improving juice yield, quality, and shelf life [46]. Huang et al. [47] designed a biocompatible magnetic chitin nanofiber biocomposite using GLU cross-linker and used as a novel support material for chymotrypsin immobilization with excellent catalytic properties (Figure 3). The GLU-cross-linked insolubilized enzymes exhibited $70.7 \%$ of its original activity by incubating at $60^{\circ} \mathrm{C}$ for $3 \mathrm{~h}$, whereas the non-immobilized chymotrypsin showed only $29.6 \%$ of activity under identical conditions. After storage for 20 days, the immobilized nanobiocatalyst presented $84.9 \%$ of the initial activity, as compared to $18.8 \%$ for the free enzyme. After enzyme immobilization onto this magnetic nanobiocomposite, the loading capacity of the enzyme was improved up to 6.3-fold following GLU cross-linking. Moreover, the immobilized biocatalyst was easily recovered and recycled from the reaction mixture [47].

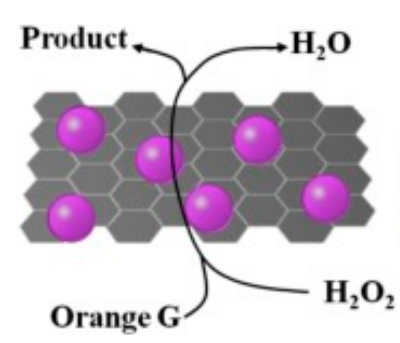

a

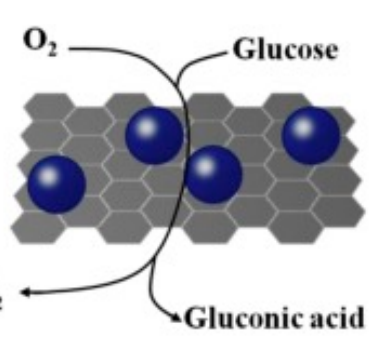

Gluconic acid

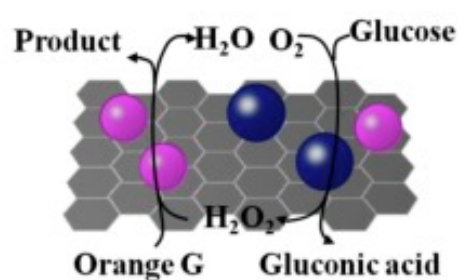

b

\section{GO/ $\mathrm{Fe}_{3} \mathrm{O}_{4} \odot \mathrm{CPO} \odot \mathrm{GOx}$}

Figure 2. (a) Mass transfer resistance between chloroperoxidase (CPO) and glucose oxidase (GOx) for MGO-GOx+MGO-CPO; (b) no mass transfer resistance between CPO and GOx for MGO-GOx-CPO. Reprinted from Gao et al. [19], with permission from Elsevier. Copyright (2018) Elsevier B.V.

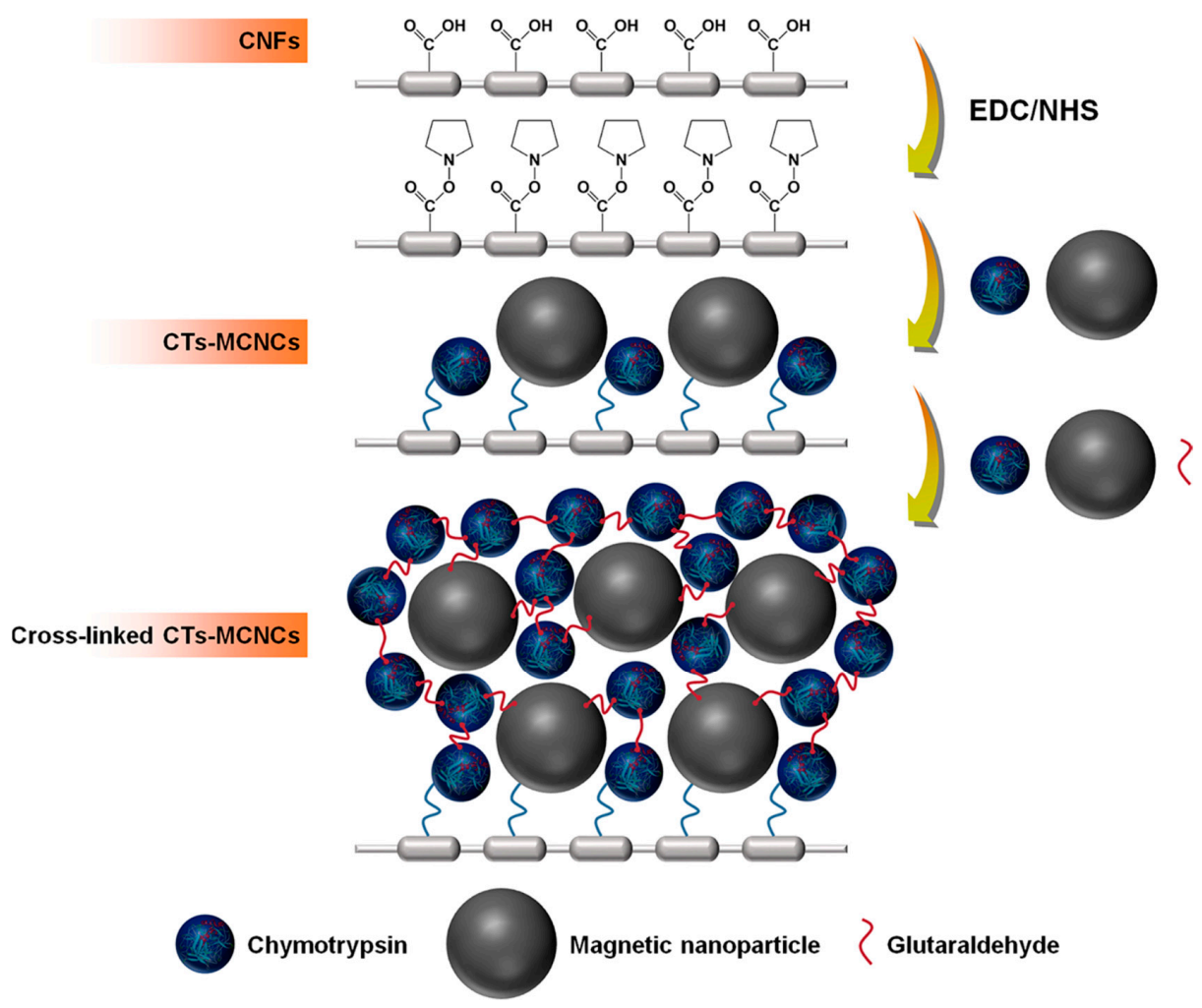

Figure 3. Schematic illustration of the immobilization of chymotrypsin onto the magnetic chitin nanofiber composite. Reprinted from Huang et al. [47], with permission from American Chemical Society. Copyright (2018) American Chemical Society. 
Cross-linking agents play a critical role and have a direct effect on activity recovery and functional stability during cross-linking of the enzymes on nano-supports. Glutaraldehyde is considered the preferred cross-linking agent amongst a range of protein cross-linkers due to its cheapness, easy availability, and manipulation and the ability to form covalent bonding with the majority of the enzymes [48]. Nevertheless, some inherent drawbacks are associated with the use of glutaraldehyde as a cross-linker. The use of GLU cross-linker, in some instances, led to complete enzyme deactivation by penetrating into the catalytic site and cross-linking with biocatalytically important amino acids residues due to its small size [49]. Moreover, GLU-assisted cross-linking of enzyme molecules forms enzyme lumps that hinder the active sites resulting in mass transfer resistances and diminished catalytic efficiency [50]. Consequently, polysaccharides-based cross-linkers have gained great attention in the past years for cross-linking of proteins over the use of GLU. Sojitra and coworkers [29] synthesized magnetic tri-enzyme nanobiocatalyst by insolubilizing three enzymes, i.e., $\alpha$-amylase, pectinase and cellulase onto chitosan MNPs using dextran polyaldehyde as a macromolecular cross-linker and utilized for fruit juice clarification. As compared to the soluble enzyme, the MNPs-immobilized biocatalysts presented more than 2-folds increment in half-life and enhanced tolerance to lower $\mathrm{pH}$. Identical $K_{\mathrm{m}}$ and $V_{\max }$ values of the native and immobilized forms of pectinase revealed that conformational flexibility of enzyme was not altered after immobilization. In addition, the magnetic tri-enzyme presented $41 \%, 53 \%$, and $46 \%$ reduction in turbidity for the clarification of apple, pineapple, and grapes juices after $2.5 \mathrm{~h}$ treatment. Results revealed that magnetic nanobiocatalysts might be a suitable technology for fruit juice clarification, owing to its possibility to separate enzymes from the reaction mixture and, subsequently, the reutilization of biocatalysts in multiple reaction cycles [29]. A significant improvement in $\mathrm{pH}$ and thermal stability of pectinase from Penicillium oxalicum $\mathrm{F} 67$ has also been achieved by immobilizing enzyme onto magnetic cornstarch microspheres. The resultant biocatalyst displayed about $60 \%$ of its preliminary activity after eight successive reuses for apple juice processing [30].

\subsection{Biotransformation of Inulin to High Fructose Syrup}

Inulin is a polysaccharide made up of fructose monomers and seems to be an abundant source for the production of fructooligosaccharides and fructose syrup in pharmaceutical and food industries. As a low caloric sweetener and prebiotic, fructooligosaccharides possess human health promoting effects such as a reduction in serum triglyceride and cholesterol levels, and significant improvement in the intestinal microbial flora [51,52]. Fructose is an inexpensive, low-calorie, and GRAS-approved sweetener and utilized as a safe alternative sweetener in diabetic patients [53]. Inulinase (EC:3.2.1.7) is well-known hydrolytic biocatalyst that can produce a high level of pure fructose syrup from inulin by a one-step enzymatic process in contrast to uneconomical and hazardous acid hydrolysis, as well as, multi-step enzymatic starch breakdown by glucoamylase, glucose isomerase, $\alpha$-amylase, and pullulanase [54,55]. Due to lower solubility and high microbial contamination of inulin in the water at room temperature, industrial-scale inulin hydrolysis needs to be executed at elevated temperatures for higher inulin substrate utilization due to the increased solubility [56]. Therefore, thermostable inulinases are desirable biocatalysts for the chemical and food industry. In this context, Torabizadeh and Mahmoudi [25], covalently attached inulinase from Aspergillus niger onto wheat gluten hydrolysates (WGHs)-functionalized $\mathrm{Fe}_{3} \mathrm{O}_{4} \mathrm{MNPs}$ in the presence of glutaraldehyde as a cross-linking agent. As-developed inulinase was found to be active over a broader $\mathrm{pH}$ and temperature ranges, and also exhibited pronounced storage and thermal stability. The inulinase showed 12.3 folds rise in enzyme half-life value following immobilization on MNPs at $75^{\circ} \mathrm{C}$ and retained $70 \%$ of its preliminary catalytic activity after 12 continuous inulin hydrolysis cycles [25]. More recently, Mohammadi et al. [23] fabricated unique biocompatible support i.e., glutathione-coated gold MNPs (GSH-AuMNPs) and used for the covalent immobilization of the inulinase enzyme (Figure 4). The resulting magnetically recoverable and solid biocatalyst was applied for efficient biotransformation of inulin to high fructose syrup. After immobilization, the storage stability and reusability of inulinase were considerably 
improved, and the immobilized biocatalyst preserved about $78 \%$ of its original activity after 10 repeated cycles. Immobilization on MNPs improved the enzyme performance at acidic pHs (3.0 and 4.0) and high temperature up to $80{ }^{\circ} \mathrm{C}$. Chromatographic results revealed the complete hydrolysis of inulin and the end-products of both free and immobilized biocatalytic systems only consisted of $98 \%$ of fructose and up to $2 \%$ of glucose. The findings demonstrated that the magnetic nanomaterials-immobilized inulinase might display a high potential for larger scale synthesis of high fructose syrup and fructooligosaccharides useful for biotechnological, food, and biomedical industries [23].

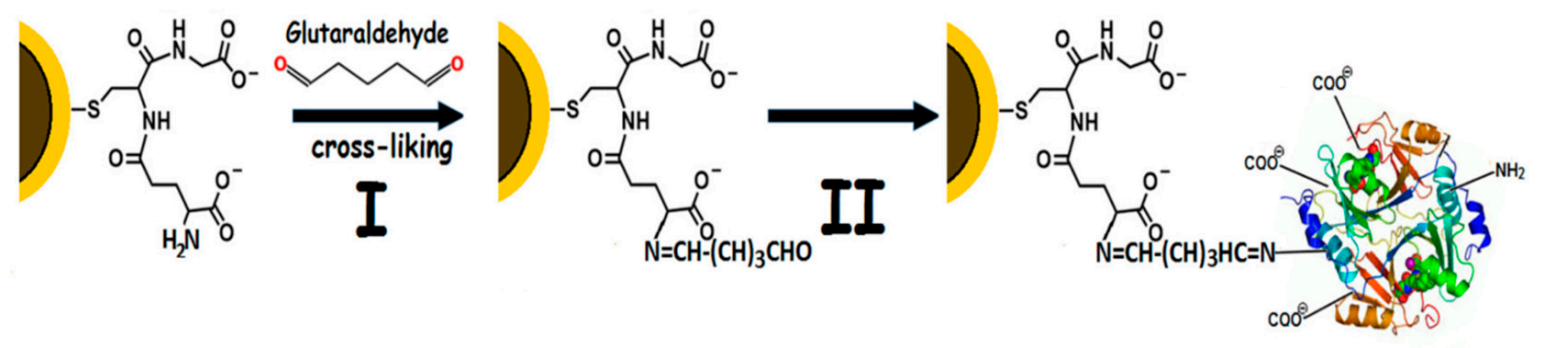

GSH-AuMNPS

Activated GSH-AuMNPs

Enzyme immobilized on GSH-AuMNPs

Figure 4. Enzyme immobilization steps including (I) cross-linkage of glutathione decorated $\mathrm{Fe}_{3} \mathrm{O}_{4}$ - $\mathrm{Au}$ magnetic nanoparticles (GSH-AuMNPs) with GA, and (II) enzyme immobilization on GSH-AuMNPs surface. Reprinted from Mohammadi et al. [23], with permission from Elsevier. Copyright (2018) Elsevier B.V.

\subsection{Other Applications}

In recent years, fabrication of virus-like structured particles has appeared as one of the most creative and state-of-the-art support materials for enzymes immobilization. These novel materials offered a noteworthy biocatalytic platform enabling the durable stability and reusability of the enzymes [57]. For instance, P22 virus-like particles [58], Q $\beta$ virus-like particles [59], and cowpea chlorotic mottle virus particles $[60,61]$ have been effectively created and employed for the enzyme immobilization. To date, a range of enzymes has been encapsulated onto these virus-like nano-carriers with the significant activity retention against extreme $\mathrm{pH}$ and temperature ranges [57]. For the first time, Jiang and coworkers [20] successfully synthesized hydrophobic virus-like organosilica nanoparticles (VOSNs) with a spherical core (Figure 5A) and employed for the covalent binding of the Candida antarctica lipase B (CALB). The synthesized hydrophobic VOSNs secured the active conformation of the CALB from the external hazardous environment because of stronger hydrophobic interfaces between the CALB molecules and VOSNs. As a result, the newly developed CALB@VSNs (Figure 5B) presented superior $\mathrm{pH}$ and thermal resistance, high tolerance to organic solvents and long-term storage stability. Under the optimized operating conditions, the CALB@VOSNs efficiently catalyzed the esterification reaction of levulinic acid and n-lauryl alcohol. Interestingly, it maintained $75.7 \%$ of the levulinic acid transformation even after nine continuous biocatalytic cycles [20].

Recently, subject to the requisite application, enzymes have been integrated with nanomaterials as immobilization carriers to engineer nano-biocatalysts [62]. Hosseini et al. [21] prepared new nano-magnetic biocatalyst particles following immobilization of CALB onto chitosan-cross-linked MNPs (Figure 6). The as-synthesized CALB-immobilized nanoparticles showed high storage stability and repeatability because of tightly cross-linked chitosan structure and covalent bonding. The newly developed magnetic biocatalyst efficiently catalyzed the ring opening esterification of itaconic anhydride as compared to the free enzyme [21]. In another study, C. rugosa lipase (CRL) coupled to new zwitterionic polymer-grafted silica nanoparticles (SNPs-pOD-CRL) displayed substantially improved enzyme-substrate affinity and catalytic performance than soluble enzyme due to the activation of lipase by the hydrophobic alkyl chains of the polymer (Figure 7) [63]. Moreover, a significant increase in thermal stability profile indicates that zwitterionic polymer with shorter alkyl side chains is advantageous to develop thermostable enzymes [63]. Of most recent, Suo et al. [24] developed a novel 
immobilization strategy to increase the catalytic stability of lipase enzyme. In this method, lipase was adsorbed on ionic liquid (IL) modified magnetic chitosan (MCS) composites and graphene oxide (GO) nanosheets served as shell coating for anchoring the lipase structure (Figure 8) [24]. The GO-shielded novel biocatalytic system sustained 6.72-fold high activity as compared to the free enzyme. In addition, the thermal stability was also enhanced, and the immobilized enzyme retained $92.1 \%$ of residual activity after 10 cycles of reuse [24]. Wang et al. [31] synthesized stable magnetic $\mathrm{Fe}_{3} \mathrm{O}_{4} @$ chitosan nanoparticles by an efficient and simple in-situ co-precipitation technique and used to chemically conjugate lipase from Thermomyces lanuginosus by covalent immobilization. Besides a broader $\mathrm{pH}$ and thermal tolerance, the immobilized lipase also exhibited good reusability maintaining $70 \%$ of original activity after 10 reaction batches. The nanobiocatalyst achieved higher than $50 \%$ conversion of ascorbic acid when used for ascorbyl palmitate synthesis in tert-butanol at $50{ }^{\circ} \mathrm{C}$ [31].
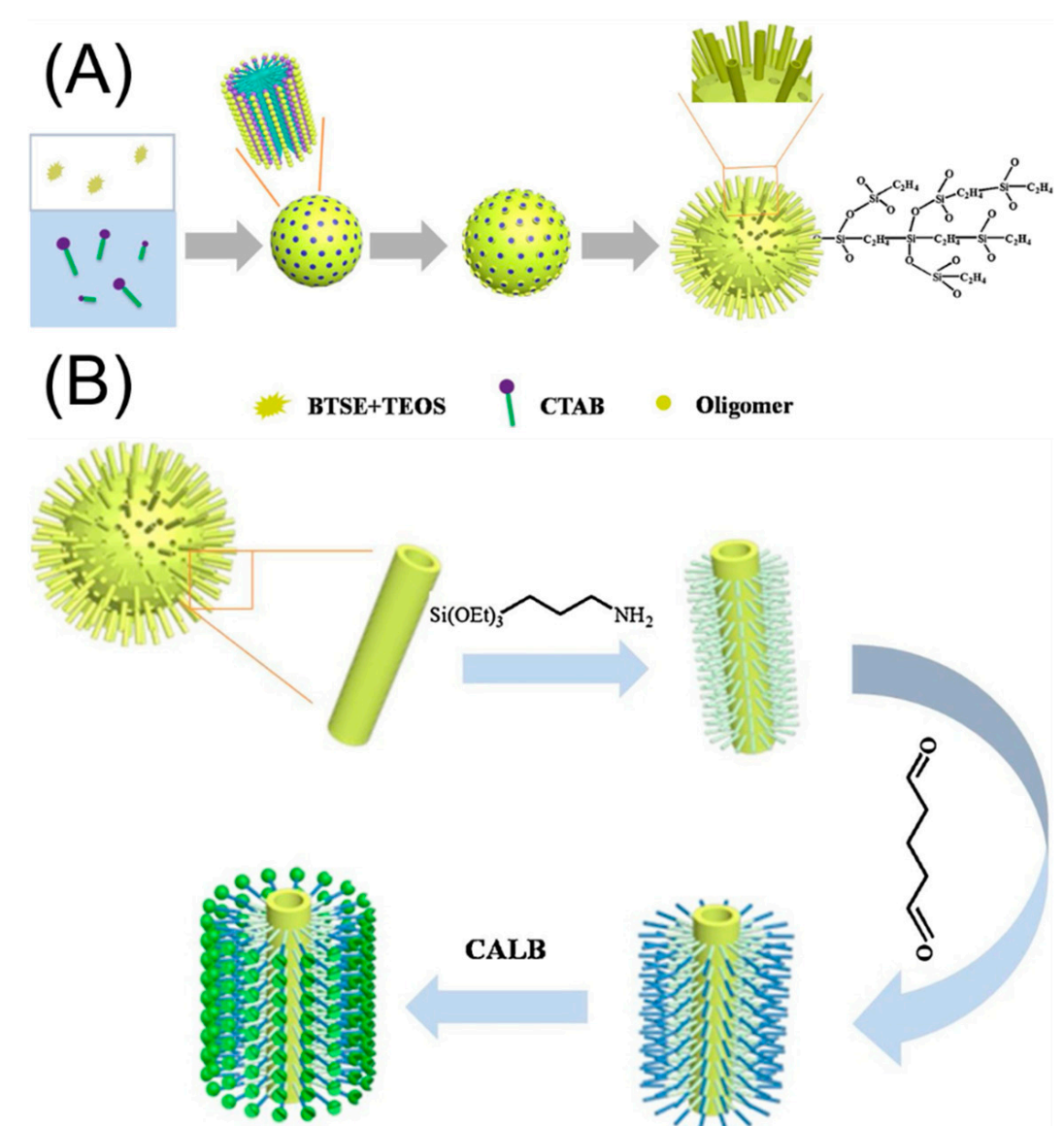

\section{CALB}
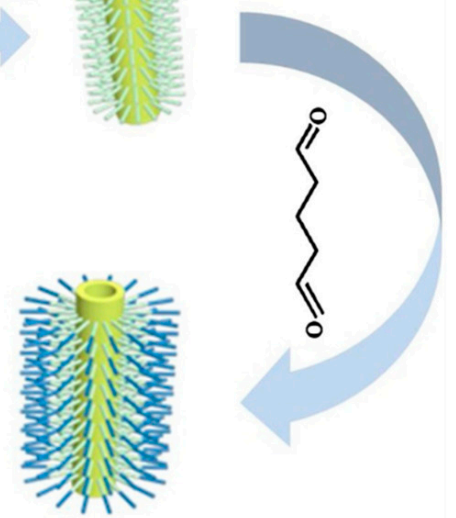

APTES

| Glutaraldehyde

- CALB

Figure 5. (A) Schematic illustration of the formation process of hydrophobic virus-like organosilica nanoparticles VOSNs and (B) preparation of the hydrophobic virus-like organosilica nanoparticles immobilized lipase B from Candida antarctica. Reprinted from Jiang et al. [20], with permission from Elsevier. Copyright (2019) Elsevier B.V. 


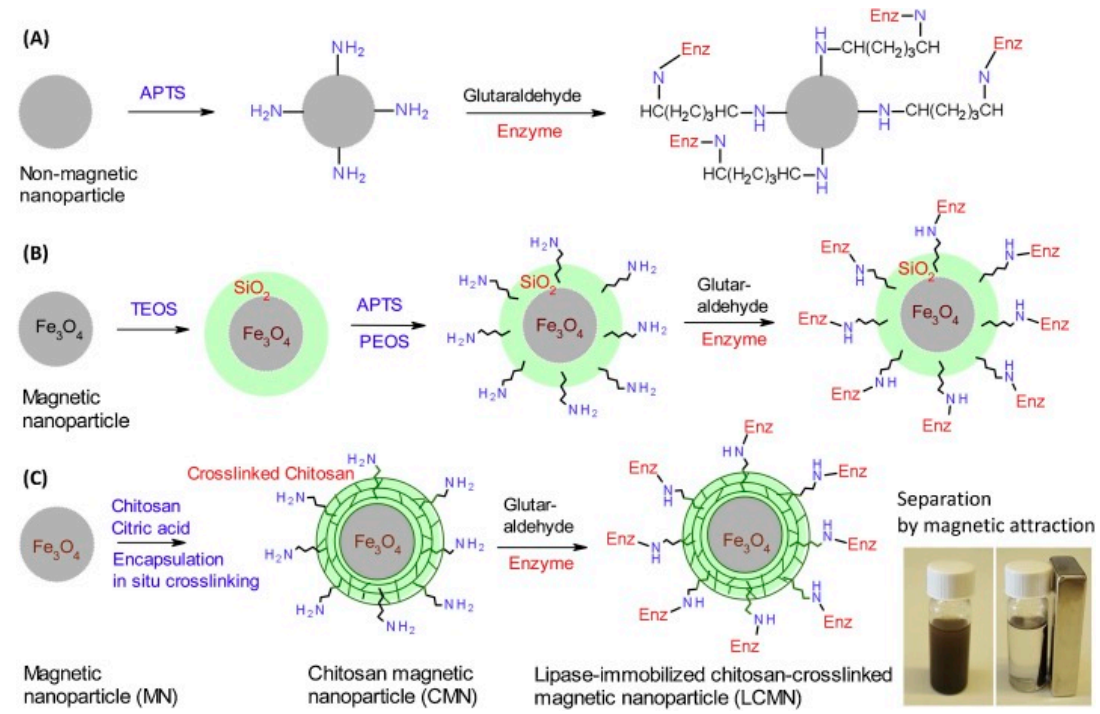

Figure 6. Representative illustrations of enzyme immobilization in the nanoparticle. (A) Conventional method using non-magnetic nanoparticle. (B) Conventional method using magnetic nanoparticle and organosilane compounds. (C) Present study using magnetic nanoparticle and chitosan crosslinked for immobilization of enzyme (lipase). APTS: 3-aminopropyltriethoxysilane, TEOS: tetra-ethoxy silane, PEOS: poly-ethoxysilane. Reprinted from Hosseini et al. [21], with permission from Elsevier. Copyright (2018) Elsevier B.V. (A) and (B) modified by Hosseini et al. [21] from Kim et al. [62], an open access article distributed under the Creative Commons Attribution License. Copyright (2018) the authors. Licensee MDPI, Basel, Switzerland.

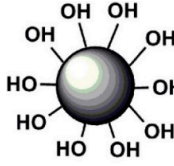

SNPs

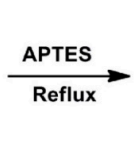

SNPs-NH

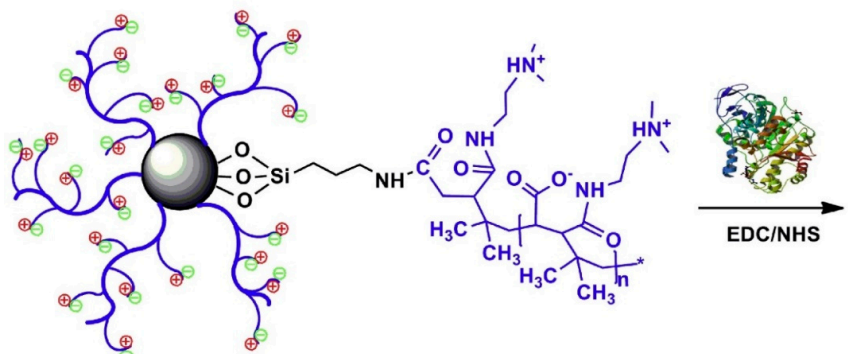

SNPS-pID

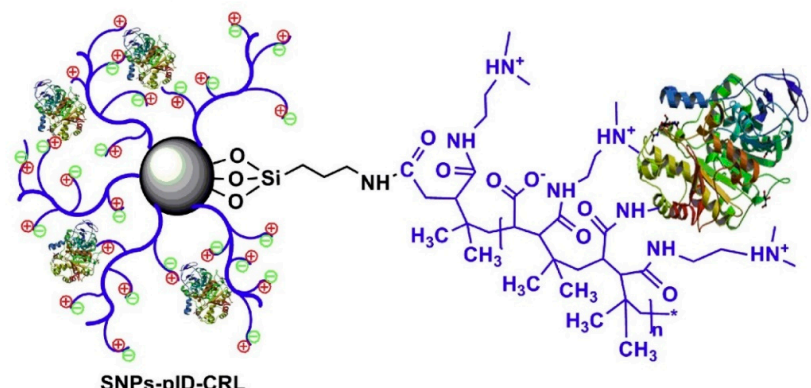

Figure 7. Schematic for the preparation of immobilized lipase on poly(4-((2-(dimethylamino)ethyl) amino)-4-oxobut-2-enoic acid-alt-isobutylene) (pID)-grafted silica nanoparticles. Reprinted from Zhang et al. [63], with permission from Elsevier. Copyright (2019) Elsevier B.V. 

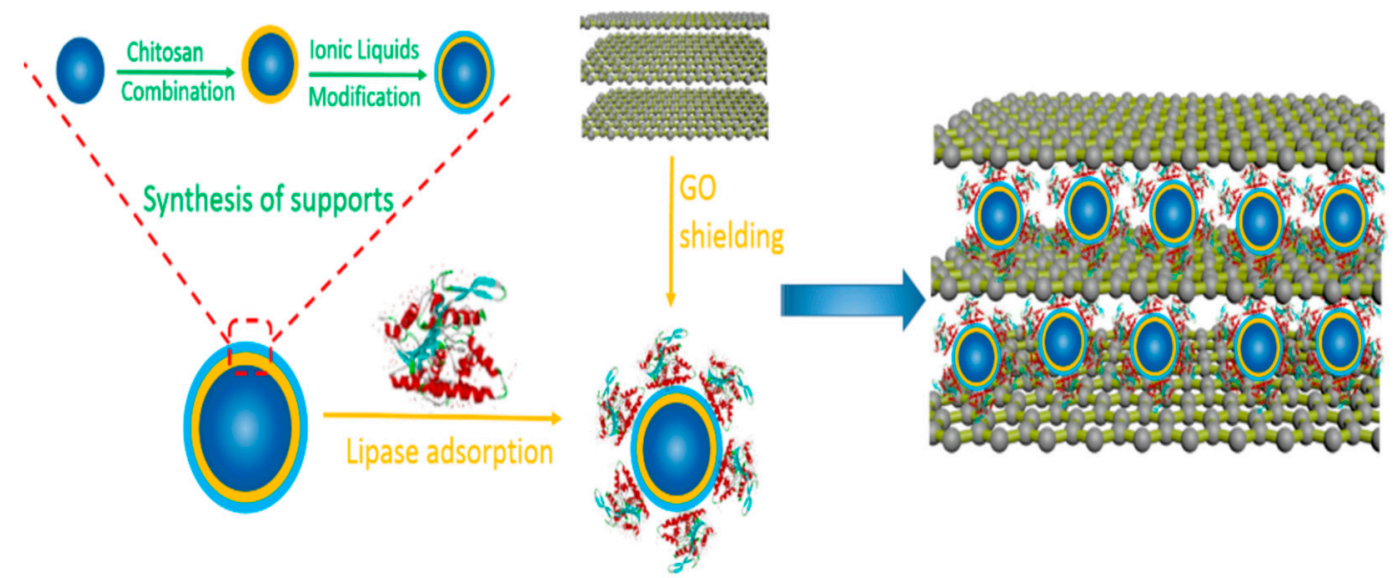

Figure 8. Immobilization of lipase on ionic liquid (IL) modified magnetic chitosan (MCS) composites using graphene oxide (GO) as shell coating. Reprinted from Suo et al. [24], with permission from American Chemical Society. Copyright (2019) American Chemical Society.

\section{Biomedical Perspectives of Magnetic Nanomaterials}

Magnetic nanoparticles are the most promising area and have a wide range in multi-disciplinary applications because of its unique features such as eco-remediation, biological purification, magnetic fluids, and a number of biomedical applications including hyperthermia mediated cancer treatment, biosensors for disease detection (MRI), and site-specific drug delivery. It varies in size from few to tens of nanometers $(\mathrm{nm})$ [64]. It means MNPs are smaller than a cell $(10-100 \mu \mathrm{m})$, protein $(5-50 \mathrm{~nm})$, gene ( $2 \mathrm{~nm}$ wide and 10-100 $\mathrm{nm}$ long), and virus (20-450 nm). Its small size makes enable to get closer to the desired targets. Although, NMPs coated with some biological interacting molecules that enable it to penetrate or tag the biological object [65]. MNPs obey the coulombs law that means it can be deployed by any outward magnetic gradient. These properties of MNPs open up the new site for immobilization or transportation of MNPs into the biological systems including human tissues. Therefore, these particles can act as a protective shield to deliver the variety of drugs especially anticancer, radionuclide entities, and target the hard sites of the human body like brain [66]. Another MNPs advantage is to response against the resonance applied by external system as a result transfer of energy from an excited medium to nanoparticles can be used for detection. For instance, hyperthermia is a nearly acceptable technique that is used for the treatment of cancer along with chemotherapy or radiotherapy, because it induces minimal damage to normal cells. In this technique, particles are used that act as hypothermic mediators [67]. These particles transfer the heat beyond the threshold level that are enough to kill the cells present in the cancer microenvironment. In various envisioned applications of MNPs, the size of the particles play a crucial role in the functionality, for example in various envisioned applications of particles are depends upon the size [68]. The particles have below critical size perform well. These particles are considered as a single functional magnetic domain which shows superparamagnetic properties when exceed the temperature threshold value. Sometime individual particles showed constant paramagnetic behavior and act like gigantic paramagnetic entity. These giant particles have a very quick response to the remnant magnetization or residual magnetization (magnetic force remains after external magnetization removed) and coercive force (the field required to bring the magnetization to zero). These distinctive features of particles make them very strong and potential candidate in biomedical applications [69-71].

Preparation of NPs are usually fall in the inductive method (bottom-up). In this method, NPs are fabricated from an atom level to the molecular level through self-organization pattern. In biomedical applications, core-shell of NPs is from the magnetic origin than make it more stable, compatible, and fast-penetrating through encapsulated with organic or inorganic polymers [72]. These supportive modifications enable them to use in various biomedical applications. Although morbidity rates globally comparatively decrease with the advancement in medical science, cancer is still one of the biggest 
contributors to increase the mortality rate. Albeit according to the ACS (American Cancer Society) report mortality rate due to cancer decreased in the past few years. This is because of early diagnosis, target specific treatment, and decrease in smoking [73]. The conventional mode of treatment including chemotherapy, radiotherapy, sometimes surgery, and immunotherapy are unable to access and target the core micro tumor environment. Currently, combinatorial therapy also called multimodal treatment in which immunotherapy (relative advance), chemotherapy, and radiotherapy are used in combine fashion to get better results in cancer treatment [74].

Therefore, specific and targeted drug delivery provides a good opportunity to treat diseases. For the drug delivery, small particle (micro or nanoparticles) are being used to get momentous results including: (1) targeting the core area of a diseased body organ; (2) reducing the concentration of drug that is conquered by the surrounding cells of the target area; (3) reducing the maximum uptake of drugs by non-target cells that maximized the efficacy of drugs. Due to these reasons, the NP application graph exponentially increased in previously published articles (Figure 9) [75].

150000

112500

75000

$\sqrt{2-10}$

37500

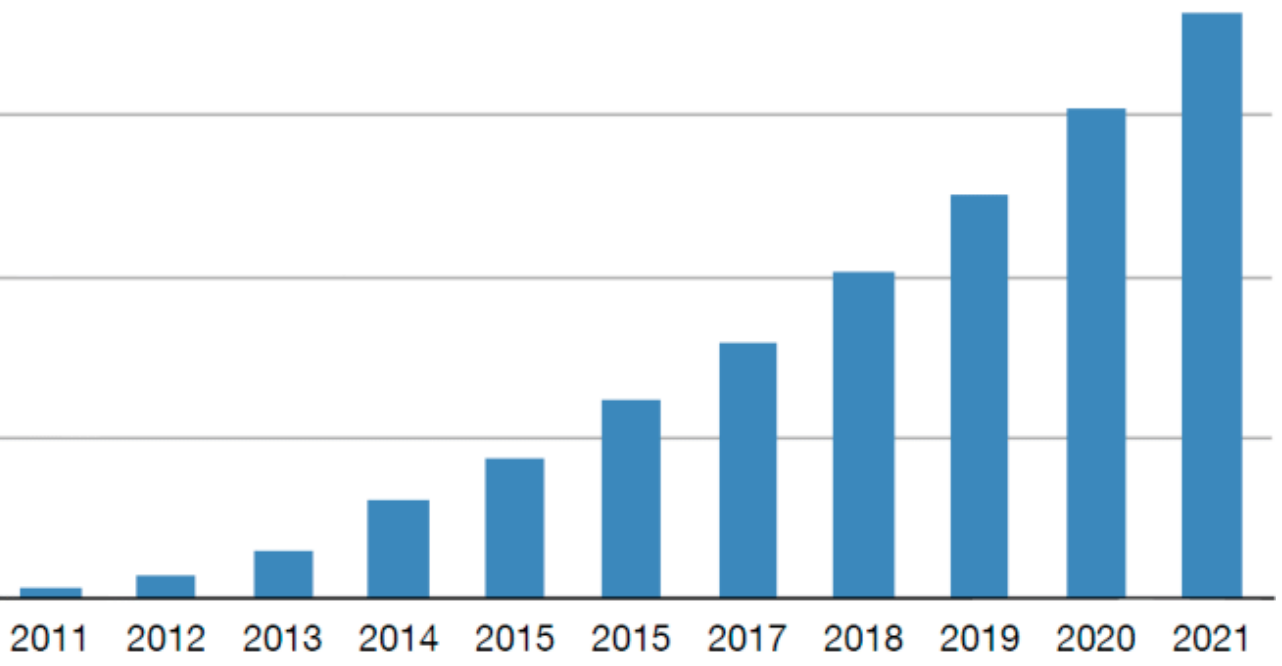

Figure 9. Global market trends for nanotechnology in drug delivery 2011-2021. Adopted from “Market Opportunities in Nanotechnology Drug Delivery". Available at: http://www.cientifica.com/marketopportunities-in-nanotechnology-drug-delivery/. Last accessed 9 May 2019.

NPs can easily internalization in tissue and cells because it can be phagocytosed due to its small size. Magnetic NPs based targeted delivery follows both the pattern of targeting active and passive target delivery. Previously reported that tumor microenvironment is highly permeable and drippy, so it called extravasation as a result of NPs target the tumor passively. These factors combine to enhance the permeability and retention of NPs so this phenomenon is known as enhanced permeation and retention (EPR) [76]. Along with all above-mentioned advantages, NPs have some limitations other than size. The main concern with NPs is the retention time in bloodstream. Therefore, the big problems with passive delivery of conventional NPs are that (i) they only target the reticuloendothelial system or mononuclear phagocyte system (MPS) and related organs including spleen, bone marrow, and liver; and (ii) they are unable to access the other tumor target sites or drug concentration is below the therapeutic level $[68,77,78]$.

Previous studies have shown that in tumor cells were overexpressed different receptors such as G protein-coupled receptor GPR87 (pancreatic cancer) [79], GPR161 (Breast cancer) [80]. Therefore, active targeting vectors have been designed that are delicate to change in temperature, light, sound, magnetism, and $\mathrm{pH}$ and mounted it with drugs. Active targeting may be dependent on over-expression of low molecular weight species including Folic acid, sugars, thiamine, hyaluronic acid, transferrin, DNA, etc. [81,82]. There are different types of NPs such as Liposomes, polymeric micelles; polymeric 
nanoparticle, emulsions, and nanogel are used for specific target delivery. These NPs are different in chemical nature, size, physical properties (light, temperature, $\mathrm{pH}$, electric charge), hydrophobicity, hydrophilicity and pattern of conjugated with drugs (attached, adsorbed, encapsulated) [10]. Hereby, in this section, we mainly address the MNPs.

\subsection{Efficacy of Nanoparticles-Based Drug Delivery}

With the advancement of drug formulation, the designing of target-specific drugs is always the central and most discussed issue. Nanoparticle-based drug delivery is one of the most considerable and suitable options for target drug delivery. There are several reasons to considering the nanoparticle for a theranostic carrier and agent. Conventional drugs are administered through intravenous or oral dosing. Consequently, these drugs are not always be formulated at optimal dosage. Similarly, sometimes drug formulation is based on degradable biomolecules such as oligos, nucleotides, and proteins. Therefore, these kinds of drugs need an innovative and specifically targeted carrier system that thwarts them from annoying degradation [83,84]. It is reported that drug delivery system is directly linked to the size of particles because the large surface area with small size that enhances the physiochemical properties of particle including bioactivity, solubility, passes the blood-brain barrier (BBB), and crosses the skin endothelial cells [85]. Nanoparticles that are constructed from biodegradable (natural) and non-biodegradable (synthetic) polymers have envisaged the potential customized nanoparticles for drug delivery that help to escape the drugs from the endogenous invasion of enzymes [84]. Another advantage of introducing reliable drug delivery system that increase the sale growth rate of pharmaceutical companies. The state-of-the-art delivery system leads the companies to introduce new drug formulation and minimize the side effects of the drugs. Therefore, these innovative amendments will be valuable for patients [86]. Moreover, this not only increases the company's growth rate but also encourage the innovators to introduce new patents [87]. This nanotechnology will also offer new life to that drugs that are unmarketable due to the high toxicity, low bio absorptivity, etc. (Figure 10) $[88,89]$.
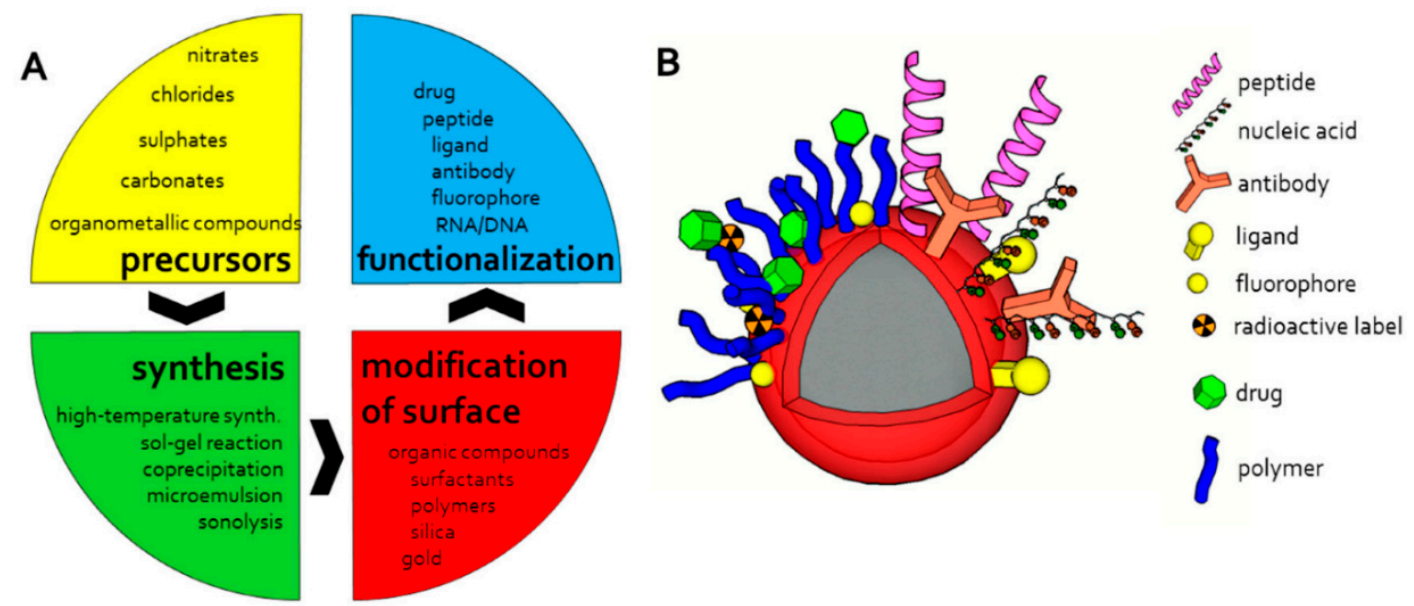

Figure 10. Scheme of magnetic particles design workflow (A) and possible modification and functionalization of magnetic particles (B). Reprinted from Kudr et al. [89], an open access article distributed under the Creative Commons Attribution License. Copyright (2017) the authors. Licensee MDPI, Basel, Switzerland.

\subsection{Iron-Based MNPs for Biomedical Applications}

Iron (transition element) is the most important and fourth copious element of earth's crust, as well as, considered as the backbone of modern infrastructure, around the globe. In past years, iron-based nanoparticles were abandoned due to its oxides and other renowned metals including nickel, cobalt, platinum, and gold. Nowadays, the development of iron-based MNPs is a trend in the field of nanoscience. Comparative analysis of ferromagnetic properties of iron with other magnetic material 
has shown that iron is the leading element for nanoparticles applications. For example, gadolinium has low Curie temperature (Tc), that is below the room temperature and it shows high saturation magnetization $(\sigma \mathrm{s})$ at $0 \mathrm{~K}$. Therefore, it is impractical in most of the experiments. Iron has high enough $T c$ and os that are near to the optimum status in most of the experiments. Moreover, iron also shows via magnetocrystalline anisotropy that it was more feasible for work. Superparamagnetic behavior and maximum volume particles of iron at the required temperature is directly linked to magneto-crystalline anisotropy. This means that superparamagnetic behavior is much better and workable than any other metal nanoparticles.

Other than the magnetic feature, momentous features of iron nanoparticles that have been shown that these are less expensive, revealed the adequate biophysical and biochemical stability and compatibility as well as eco-friendly $[76,90,91]$. Surface modification of the MNPs is an integral part of defining the physiochemical properties and stability as well $[92,93]$. Surface modification elements should have a strong affinity with iron and also have functional compatibility [94]. Magnetite $\left(\mathrm{Fe}_{3} \mathrm{O}_{4}\right)$ nanoparticles have been synthesized through Massart method and co-precipitation. These nanoparticles have varied between 7 to $13 \mathrm{~nm}$ in size. Later on, through the chemical alteration of $\mathrm{Fe}_{3} \mathrm{O}_{4}$ by aeration oxidation process were converted into maghemite $\left(\gamma-\mathrm{Fe}_{2} \mathrm{O}_{3}\right)$ nanoparticles. These nanoparticles have greater biocompatibility, stability in the diverse field, and they demonstrate better heating capability [95]. Maghemite nanoparticles can also be used in ferrofluid that has an immense range of application in biomedicine, such as targeted drug delivery, hyperthermia in tumor treatment, and cell sorting and manipulation [96]. There is a number of methods to be implicated on maghemite nanoparticle synthesis including microemulsion [97], co-precipitation [98], organic decomposition at high temperature [99], and oxidation [100]. Similarly, there are many other ways to synthesize the iron MNPs, but innovative approaches are still needed for commercial production and environmental-friendly nanoparticles [101]. For iron oxide nanoparticles synthesis, sodium oleate, and iron chloride were mixed and add this mixture into cocktail solvent of hexane, ethanol, and water than heat it to get the waxy iron-oleate complex. Afterward, this complex mixed with oleic acid, dissolved into 1-octadecene and heated. Poly(D, L-lactide-co-glycolide) have a wide range of applications in biomedical sciences due to its non-toxic nature, biocompatibility, and bio-resorptive nature [102,103]. Therefore, MNPs-coated with this polymer is very fascinating and catch the attention of biomedical experts. Poly(D, L-lactide-co-glycolide) coated superparamagnetic iron oxide nanoparticles are widely used in MRI as a contrasting agent. For the preparation of this nanoparticle reaction of iron (III) acetylacetonate with 1,2-hexadecanediol, oleic acid, oleylamine, and phenyl at $260{ }^{\circ} \mathrm{C}$ in acidic $\mathrm{pH}$ [104]. polyethylene glycol (PEG) and polyethyleneimine (PEI) [105-107] coated superparamagnetic iron oxide nanoparticles are synthesized by co-precipitation method and cathodic electrochemical deposition (CED) [108] are a more effective method for this. Nanoparticles coated with PEG-PEI have shown high affinity to bind with DNA phosphate backbone [109].

There are the special amendments that have been occurred according to the area of applications such as improving the molecular images. A distinct group of MNPs having composite with the variety of different metal dopants (trace impurity elements) including M2+, Mn, Zn, Ni, or Co. Metal-doped iron oxides $\left(\mathrm{MnFe}_{2} \mathrm{O}_{4}, \mathrm{FeFe}_{2} \mathrm{O}_{4}, \mathrm{CoFe}_{2} \mathrm{O}_{4}\right.$, and $\left.\mathrm{NiFe}_{2} \mathrm{O}_{4}\right)$ based nanoparticles were synthesized at high temperature and reaction occurred between the iron tris-2,4-pentadioate and divalent metal chloride $[110,111]$. Toxicological analysis of metal-doped nanoparticles has expressed that $\mathrm{MnFe}_{2} \mathrm{O}_{4}$ showed any toxicity in-vitro. While the other $\mathrm{Co}$ and $\mathrm{Ni}$ toxicity were limiting factors for their use [90]. Finally, the most imperative facet is to construct nanoparticles according to explicit biological applications, for example, magnetic fluid hyperthermia, thermoablation, targeted drug delivery, magnetic separation, and MRI [112].

\subsection{Cobalt-Based MNPs for Biomedical Applications}

Cobalt-based nanoparticles are rarely used in biomedical science due to their toxicity. However, in some cases, possible modification reduces the toxicity, for example, above-mentioned dopant 
based MNPs $\left(\mathrm{CoFe}_{2} \mathrm{O}_{4}\right)$ [112] and metal alloy MNPs $\left(\mathrm{Fe}_{12} \mathrm{Co}_{88}, \mathrm{Fe}_{40} \mathrm{Co}_{60}\right.$, and $\left.\mathrm{Fe}_{60} \mathrm{Co}_{40}\right)[112,113]$. There is the only way to make it applicable to biological systems. Commercially existing carbon-coated cobalt nanoparticles were functionalized with polyhydroxy-, polyamine-, or PEG2000-functionalized Dendron's or polymers and designed for theoretical biomedical applications as drug carriers [114]. Previous work reported that magnetic cobalt nanoparticle is auspicious material for retinal detachment cure if these nanoparticles were conjugated with poly (dimethylsiloxane), dicobalt octacarbonyl $\mathrm{Co}_{2}(\mathrm{CO})_{8}$ [115]. Similarly, the above-mentioned application of cobalt that were only testified to repair the detach retina [116]. An altered polyol-process was pragmatic for crystalline cobalt nanoparticles with the possible implication in biomedicine [117].

\subsection{Other MNPs for Biomedical Applications}

In the traditional point of view refined form of $\mathrm{Fe}_{3} \mathrm{O}_{4}$ and $\gamma-\mathrm{Fe}_{2} \mathrm{O}_{3}$-based superparamagnetic nanoparticles are widely used. Some other materials that have desired features like $\mathrm{Y}_{3} \mathrm{Fe}_{5} \mathrm{O}_{12}, \mathrm{SrFe}_{12} \mathrm{O}_{19}$, or $\mathrm{SmCo}_{5}$ were also used [118]. However, the major problem with these materials is they are not prepared by conventional methods. These materials are separated and prepared by advanced methods like submicron particle preparation [119]. Another type of nanoparticle is based on Ni with different chemical modifications. Ni nanocrystals were encapsulated with carbon moieties $\mathrm{Ni}_{3} \mathrm{C}$ phase in the core of the nanoparticles [120] and second modification was on the surface by NiO [121]. Similar, EDTA-caped $\mathrm{NiO}$ nanoparticles have been prepared by co-precipitation method, while nickel chloride hexahydrate, sodium hydroxide, and EDTA (optionally) served as reagents [89,122].

\section{Concluding Remarks and Future Perspectives}

Nanomaterials are being widely investigated as a powerful carrier for biomolecules immobilization, therapeutic, and other nanobiomedical applications. Immobilization of enzymes onto nanomaterial is highly encouraging in terms of catalytic activity, enhanced stability, and reusability. Amongst various immobilization techniques, the utilization of NPs is well perceived owing to the high-specific surface area, and thereby high biocatalyst loadings. Particularly, MNPs are becoming increasingly important in the immobilization arena because of their exceptional attributes including biocompatibility, uniform particle size, high surface area to volume ratio, and the recovery of the enzyme using an external magnetic field. Moreover, many MNPs possess noteworthy results in targeted-drug delivery MRI or theranostics. Therefore, MNPs can be anticipated to be the 'material of the future', which will considerably influence all areas of nano-biomedicine. However, despite the tremendous human health-related advantages of nanomaterials, concern has been raised regarding the adverse effects of these nanomaterials. Potential routes for drug delivery are also associated with the possible entry of toxic nanomaterials into the human body. For instance, inhalation-based drug delivery has been widely applied approach for direct delivery of drugs to the bloodstream, and the same route is particularly vulnerable to toxic nanomaterials. Similarly, drug delivery via the olfactory system has also arisen the toxicity issue of nanoparticle via the olfactory system. Therefore, in parallel to extensive research advances on the use of nanoparticles for biomedical purposes, their profound impact on human health also need to be deliberated by the same research. With particular reference to MNPs and their deployment in drug delivery, the following should at least be considered prior to designing MNP-based drug delivery systems. Aiming to uplift the unresolved problems associated to the MNPs based drug delivery, future studies should cover: (1) all types of toxicity issues, i.e., cytotoxicity, hemotoxicity, teratogenicity, and mutagenicity; (2) biocompatibility including cellular-compatibility and hematocompatibility; (3) immunogenicity and mutagenicity; and (4) biodegradation and/or effective release 'removal fate' from the body after targeted delivery. Encapsulation and/or coating of active MNPs using inert materials offer considerable potentialities for future research and could further limit the toxicity of free MNPs. 
Author Contributions: Conceptualization, M.B. and H.M.N.I. Literature review, S.M., and T.R.; Writing-Original Draft Preparation, M.B., S.M., T.R., and H.M.N.I.; Figures, M.B. and S.M.; Tables, M.B.; Writing-Review \& Editing, M.B., and H.M.N.I.; Revisions \& Final editing, M.B. and H.M.N.I.; APC Funding Acquisition, H.M.N.I.

Funding: This research received no external funding. The APC (ID: magnetochemistry-513143) was funded by MDPI, St. Alban-Anlage 66, 4052 Basel, Switzerland.

Acknowledgments: All authors are thankful to their representative universities/institutes for literature services.

Conflicts of Interest: The authors report no conflict of interest in any capacity, i.e., competing or financial.

\section{References}

1. Xu, J.; Sun, J.; Wang, Y.; Sheng, J.; Wang, F.; Sun, M. Application of iron magnetic nanoparticles in protein immobilization. Molecules 2014, 19, 11465-11486. [CrossRef] [PubMed]

2. Bilal, M.; Zhao, Y.; Rasheed, T.; Iqbal, H.M. Magnetic nanoparticles as versatile carriers for enzymes immobilization: A review. Int. J. Biol. Macromol. 2018, 120, 2530-2544. [CrossRef] [PubMed]

3. Netto, C.G.; Toma, H.E.; Andrade, L.H. Superparamagnetic nanoparticles as versatile carriers and supporting materials for enzymes. J. Mol. Catal. B Enzym. 2013, 85, 71-92. [CrossRef]

4. Abu-Dief, A.M.; Abdel-Fatah, S.M. Development and functionalization of magnetic nanoparticles as powerful and green catalysts for organic synthesis. Beni-Suef Univ. J. Basic Appl. Sci. 2018, 7, 55-67. [CrossRef]

5. Jessie, A.; Guillaume, W. Tumor-Targeting Drug-Loaded Particles. U.S. Patent US8043631B2, 3 October 2012.

6. Bazile, D.; Couvreur, P.; Lakkireddy, H.R.; MacKiewicz, N.; Nicolas, J. Functional PLA-PEG Copolymers, the Nanoparticles Thereof, Their Preparation and Use for Targeted Drug Delivery and Imaging. Patent EP2634179A1, 14 June 2016.

7. Laurent, S.; Forge, D.; Port, M.; Roch, A.; Robic, C.; Vander Elst, L.; Muller, R.N. Magnetic iron oxide nanoparticles: Synthesis, stabilization, vectorization, physicochemical characterizations, and biological applications. Chem. Rev. 2008, 108, 2064-2110. [CrossRef] [PubMed]

8. Taft, D.; Tzannis, S.; Dai, W.-G.; Ottensmann, S.; Bitler, S.; Zheng, Q.; Bell, A. Polymer Formulations for Delivery of Bioactive Materials. U.S. Patent US8784893B2, 14 February 2012.

9. Angelova, A.; Angelov, B.; Drechsler, M.; Lesieur, S. Neurotrophin delivery using nanotechnology. Drug Discov. Today 2013, 18, 1263-1271. [CrossRef]

10. Martins, P.; Rosa, D.; R Fernandes, A.; Baptista, P.V. Nanoparticle drug delivery systems: Recent patents and applications in nanomedicine. Recent Pat. Nanomed. 2013, 3, 105-118. [CrossRef]

11. Ako-Adounvo, A.-M.; Marabesi, B.; Lemos, R.C.; Patricia, A.; Karla, P.K. Drug and Gene Delivery Materials and Devices. In Emerging Nanotechnologies for Diagnostics, Drug Delivery and Medical Devices; Elsevier: Amsterdam, The Netherlands, 2017; pp. 375-392.

12. Nam, J.-M.; Thaxton, C.S.; Mirkin, C.A. Nanoparticle-based bio-bar codes for the ultrasensitive detection of proteins. Science 2003, 301, 1884-1886. [CrossRef]

13. Jain, A.; Cheng, K. The principles and applications of avidin-based nanoparticles in drug delivery and diagnosis. J. Control. Release 2017, 245, 27-40. [CrossRef]

14. Yin, C.; Hong, B.; Gong, Z.; Zhao, H.; Hu, W.; Lu, X.; Li, J.; Li, X.; Yang, Z.; Fan, Q. Fluorescent oligo (p-phenyleneethynylene) contained amphiphiles-encapsulated magnetic nanoparticles for targeted magnetic resonance and two-photon optical imaging in vitro and in vivo. Nanoscale 2015, 7, 8907-8919. [CrossRef]

15. Bao, G.; Mitragotri, S.; Tong, S. Multifunctional nanoparticles for drug delivery and molecular imaging. Annu. Rev. Biomed. Eng. 2013, 15, 253-282. [CrossRef]

16. Li, L.; Jiang, W.; Luo, K.; Song, H.; Lan, F.; Wu, Y.; Gu, Z. Superparamagnetic iron oxide nanoparticles as MRI contrast agents for non-invasive stem cell labeling and tracking. Theranostics 2013, 3, 595. [CrossRef] [PubMed]

17. Wang, J.; Hu, X.; Xiang, D. Nanoparticle drug delivery systems: An excellent carrier for tumor peptide vaccines. Drug Deliv. 2018, 25, 1319-1327. [CrossRef]

18. Seenuvasan, M.; Kumar, K.; Kumar, M.A.; Iyyappan, J.; Suganthi, J. Response surface estimation and canonical quantification for the pectin degrading $\mathrm{Fe}_{3} \mathrm{O}_{4}-\mathrm{SiO}_{2}$ nanobiocatalyst fabrication. Int. J. ChemTech Res. 2014, 6, 3618-3627. 
19. Gao, F.; Guo, Y.; Fan, X.; Hu, M.; Li, S.; Zhai, Q.; Jiang, Y.; Wang, X. Enhancing the catalytic performance of chloroperoxidase by co-immobilization with glucose oxidase on magnetic graphene oxide. Biochem. Eng. J. 2019, 143, 101-109. [CrossRef]

20. Jiang, Y.; Liu, H.; Wang, L.; Zhou, L.; Huang, Z.; Ma, L.; He, Y.; Shi, L.; Gao, J. Virus-like organosilica nanoparticles for lipase immobilization: Characterization and biocatalytic applications. Biochem. Eng. J. 2019, 144, 125-134. [CrossRef]

21. Hosseini, S.M.; Kim, S.M.; Sayed, M.; Younesi, H.; Bahramifar, N.; Park, J.H.; Pyo, S.-H. Lipase-immobilized chitosan-crosslinked magnetic nanoparticle as a biocatalyst for ring opening esterification of itaconic anhydride. Biochem. Eng. J. 2019, 143, 141-150. [CrossRef]

22. Mangkorn, N.; Kanokratana, P.; Roongsawang, N.; Laobuthee, A.; Laosiripojana, N.; Champreda, V. Synthesis and characterization of Ogataea thermomethanolica alcohol oxidase immobilized on barium ferrite magnetic microparticles. J. Biosci. Bioeng. 2019, 127, 265-272. [CrossRef] [PubMed]

23. Mohammadi, M.; Mokarram, R.R.; Ghorbani, M.; Hamishehkar, H. Inulinase immobilized gold-magnetic nanoparticles as a magnetically recyclable biocatalyst for facial and efficient inulin biotransformation to high fructose syrup. Int. J. Biol. Macromol. 2019, 123, 846-855. [CrossRef]

24. Suo, H.; Xu, L.; Xu, C.; Qiu, X.; Chen, H.; Huang, H.; Hu, Y. Graphene oxide nanosheets shielding of lipase immobilized on magnetic composites for the improvement of enzyme stability. ACS Sustain. Chem. Eng. 2019, 7, 4486-4494. [CrossRef]

25. Torabizadeh, H.; Mahmoudi, A. Inulin hydrolysis by inulinase immobilized covalently on magnetic nanoparticles prepared with wheat gluten hydrolysates. Biotechnol. Rep. 2018, 17, 97-103. [CrossRef]

26. Dal Magro, L.; Silveira, V.C.; de Menezes, E.W.; Benvenutti, E.V.; Nicolodi, S.; Hertz, P.F.; Klein, M.P.; Rodrigues, R.C. Magnetic biocatalysts of pectinase and cellulase: Synthesis and characterization of two preparations for application in grape juice clarification. Int. J. Biol. Macromol. 2018, 115, 35-44. [CrossRef]

27. Mardani, T.; Khiabani, M.S.; Mokarram, R.R.; Hamishehkar, H. Immobilization of $\alpha$-amylase on chitosan-montmorillonite nanocomposite beads. Int. J. Biol. Macromol. 2018, 120, 354-360. [CrossRef]

28. Sojitra, U.V.; Nadar, S.S.; Rathod, V.K. Immobilization of pectinase onto chitosan magnetic nanoparticles by macromolecular cross-linker. Carbohydr. Polym. 2017, 157, 677-685. [CrossRef]

29. Sojitra, U.V.; Nadar, S.S.; Rathod, V.K. A magnetic tri-enzyme nanobiocatalyst for fruit juice clarification. Food Chem. 2016, 213, 296-305. [CrossRef]

30. Wang, B.; Cheng, F.; Lu, Y.; Ge, W.; Zhang, M.; Yue, B. Immobilization of pectinase from Penicillium oxalicum F67 onto magnetic cornstarch microspheres: Characterization and application in juice production. J. Mol. Catal. B Enzym. 2013, 97, 137-143. [CrossRef]

31. Wang, X.-Y.; Jiang, X.-P.; Li, Y.; Zeng, S.; Zhang, Y.-W. Preparation $\mathrm{Fe}_{3} \mathrm{O}_{4} @$ chitosan magnetic particles for covalent immobilization of lipase from Thermomyces lanuginosus. Int. J. Biol. Macromol. 2015, 75, 44-50. [CrossRef]

32. Bilal, M.; Rasheed, T.; Iqbal, H.M.; Yan, Y. Peroxidases-assisted removal of environmentally-related hazardous pollutants with reference to the reaction mechanisms of industrial dyes. Sci. Total Environ. 2018, 644, 1-13. [CrossRef]

33. Rehman, S.; Bhatti, H.N.; Bilal, M.; Asgher, M. Cross-linked enzyme aggregates (CLEAs) of Pencilluim notatum lipase enzyme with improved activity, stability and reusability characteristics. Int. J. Biol. Macromol. 2016, 91, 1161-1169. [CrossRef]

34. Rehman, S.; Wang, P.; Bhatti, H.N.; Bilal, M.; Asgher, M. Improved catalytic properties of Penicillium notatum lipase immobilized in nanoscale silicone polymeric films. Int. J. Biol. Macromol. 2017, 97, 279-286. [CrossRef]

35. Amin, F.; Bhatti, H.N.; Bilal, M.; Asgher, M. Improvement of activity, thermo-stability and fruit juice clarification characteristics of fungal exo-polygalacturonase. Int. J. Biol. Macromol. 2017, 95, 974-984. [CrossRef]

36. Amin, F.; Bhatti, H.N.; Bilal, M.; Asgher, M. Multiple parameter optimizations for enhanced biosynthesis of exo-polygalacturonase enzyme and its application in fruit juice clarification. Int. J. Food Eng. 2017, 13. [CrossRef]

37. Asgher, M.; Noreen, S.; Bilal, M. Enhancement of catalytic, reusability, and long-term stability features of Trametes versicolor IBL-04 laccase immobilized on different polymers. Int. J. Biol. Macromol. 2017, 95, 54-62. [CrossRef] 
38. Asgher, M.; Noreen, S.; Bilal, M. Enhancing catalytic functionality of Trametes versicolor IBL-04 laccase by immobilization on chitosan microspheres. Chem. Eng. Res. Des. 2017, 119, 1-11. [CrossRef]

39. Bilal, M.; Iqbal, H.M. Chemical, physical, and biological coordination: An interplay between materials and enzymes as potential platforms for immobilization. Coord. Chem. Rev. 2019, 388, 1-23. [CrossRef]

40. Bilal, M.; Iqbal, H.M. Naturally-derived biopolymers: Potential platforms for enzyme immobilization. Int. J. Biol. Macromol. 2019, 130, 462-482. [CrossRef]

41. Darwesh, O.M.; Matter, I.A.; Eida, M.F. Development of peroxidase enzyme immobilized magnetic nanoparticles for bioremediation of textile wastewater dye. J. Environ. Chem. Eng. 2019, 7, 102805. [CrossRef]

42. Kashefi, S.; Borghei, S.M.; Mahmoodi, N.M. Superparamagnetic enzyme-graphene oxide magnetic nanocomposite as an environmentally friendly biocatalyst: Synthesis and biodegradation of dye using response surface methodology. Microchem. J. 2019, 145, 547-558. [CrossRef]

43. Tapre, A.; Jain, R. Pectinases: Enzymes for fruit processing industry. Int. Food Res. J. 2014, 21, 447-453.

44. Dal Magro, L.; Hertz, P.F.; Fernandez-Lafuente, R.; Klein, M.P.; Rodrigues, R.C. Preparation and characterization of a Combi-CLEAs from pectinases and cellulases: A potential biocatalyst for grape juice clarification. RSC Adv. 2016, 6, 27242-27251. [CrossRef]

45. Echavarría, A.; Torras, C.; Pagán, J.; Ibarz, A. Fruit juice processing and membrane technology application. Food Eng. Rev. 2011, 3, 136-158. [CrossRef]

46. Jiménez-Sánchez, C.; Lozano-Sánchez, J.; Segura-Carretero, A.; Fernández-Gutiérrez, A. Alternatives to conventional thermal treatments in fruit-juice processing. Part 1: Techniques and applications. Crit. Rev. Food Sci. Nutr. 2017, 57, 501-523. [CrossRef] [PubMed]

47. Huang, W.-C.; Wang, W.; Xue, C.; Mao, X. Effective enzyme immobilization onto a magnetic chitin nanofiber composite. ACS Sustain. Chem. Eng. 2018, 6, 8118-8124. [CrossRef]

48. Barbosa, O.; Ortiz, C.; Berenguer-Murcia, Á.; Torres, R.; Rodrigues, R.C.; Fernandez-Lafuente, R. Glutaraldehyde in bio-catalysts design: A useful crosslinker and a versatile tool in enzyme immobilization. RSC Adv. 2014, 4, 1583-1600. [CrossRef]

49. Mateo, C.; Palomo, J.M.; Van Langen, L.M.; Van Rantwijk, F.; Sheldon, R.A. A new, mild cross-linking methodology to prepare cross-linked enzyme aggregates. Biotechnol. Bioeng. 2004, 86, 273-276. [CrossRef]

50. Zhen, Q.; Wang, M.; Qi, W.; Su, R.; He, Z. Preparation of $\beta$-mannanase CLEAs using macromolecular cross-linkers. Catal. Sci. Technol. 2013, 3, 1937-1941. [CrossRef]

51. Flores-Gallegos, A.C.; Contreras-Esquivel, J.C.; Morlett-Chávez, J.A.; Aguilar, C.N.; Rodríguez-Herrera, R. Comparative study of fungal strains for thermostable inulinase production. J. Biosci. Bioeng. 2015, 119, 421-426. [CrossRef]

52. Mussatto, S.I.; Aguiar, L.M.; Marinha, M.I.; Jorge, R.C.; Ferreira, E.C. Economic analysis and environmental impact assessment of three different fermentation processes for fructooligosaccharides production. Bioresour. Technol. 2015, 198, 673-681. [CrossRef]

53. Singh, R.S.; Chauhan, K.; Kennedy, J.F. A panorama of bacterial inulinases: Production, purification, characterization and industrial applications. Int. J. Biol. Macromol. 2017, 96, 312-322. [CrossRef]

54. Vandamme, E.J.; Derycke, D.G. Microbial inulinases: Fermentation process, properties, and applications. In Advances in Applied Microbiology; Elsevier: Amsterdam, The Netherlands, 1983; Volume 29, pp. 139-176.

55. Barthomeuf, C.; Regerat, F.; Pourrat, H. Production of inulinase by a new mold of Penicillium rugulosum. J. Ferment. Bioeng. 1991, 72, 491-494. [CrossRef]

56. Torabizadeh, H.; Habibi-Rezaei, M.; Safari, M.; Moosavi-Movahedi, A.A.; Sharifizadeh, A.; Azizian, H.; Amanlou, M. Endo-inulinase stabilization by pyridoxal phosphate modification: A kinetics, thermodynamics, and simulation approach. Appl. Biochem. Biotechnol. 2011, 165, 1661-1673. [CrossRef] [PubMed]

57. Wilkerson, J.W.; Yang, S.-O.; Funk, P.J.; Stanley, S.K.; Bundy, B.C. Nanoreactors: Strategies to encapsulate enzyme biocatalysts in virus-like particles. New Biotechnol. 2018, 44, 59-63. [CrossRef] [PubMed]

58. Patterson, D.P.; Prevelige, P.E.; Douglas, T. Nanoreactors by programmed enzyme encapsulation inside the capsid of the bacteriophage P22. ACS Nano 2012, 6, 5000-5009. [CrossRef] [PubMed]

59. Fiedler, J.D.; Brown, S.D.; Lau, J.L.; Finn, M. RNA-directed packaging of enzymes within virus-like particles. Angew. Chem. Int. Ed. 2010, 49, 9648-9651. [CrossRef] [PubMed]

60. Minten, I.J.; Hendriks, L.J.; Nolte, R.J.; Cornelissen, J.J. Controlled encapsulation of multiple proteins in virus capsids. J. Am. Chem. Soc. 2009, 131, 17771-17773. [CrossRef] [PubMed] 
61. Minten, I.J.; Claessen, V.I.; Blank, K.; Rowan, A.E.; Nolte, R.J.; Cornelissen, J.J. Catalytic capsids: The art of confinement. Chem. Sci. 2011, 2, 358-362. [CrossRef]

62. Kim, K.; Lee, O.; Lee, E. Nano-immobilized biocatalysts for biodiesel production from renewable and sustainable resources. Catalysts 2018, 8, 68.

63. Zhang, C.; Liu, Y.; Sun, Y. Lipase immobilized to a short alkyl chain-containing zwitterionic polymer grafted on silica nanoparticles: Moderate activation and significant increase of thermal stability. Biochem. Eng. J. 2019, 146, 124-131. [CrossRef]

64. Frimpong, R.A.; Hilt, J.Z. Magnetic nanoparticles in biomedicine: Synthesis, functionalization and applications. Nanomedicine 2010, 5, 1401-1414. [CrossRef] [PubMed]

65. Bárcena, C.; Sra, A.K.; Gao, J. Applications of magnetic nanoparticles in biomedicine. In Nanoscale Magnetic Materials and Applications; Springer: New York, NY, USA, 2009; pp. 591-626.

66. Pankhurst, Q.A.; Connolly, J.; Jones, S.; Dobson, J. Applications of magnetic nanoparticles in biomedicine. J. Phys. D Appl. Phys. 2003, 36, R167. [CrossRef]

67. Jha, S.; Sharma, P.K.; Malviya, R. Hyperthermia: Role and risk factor for cancer treatment. Achiev. Life Sci. 2016, 10, 161-167. [CrossRef]

68. Neuberger, T.; Schöpf, B.; Hofmann, H.; Hofmann, M.; Von Rechenberg, B. Superparamagnetic nanoparticles for biomedical applications: Possibilities and limitations of a new drug delivery system. J. Magn. Magn. Mater. 2005, 293, 483-496. [CrossRef]

69. Huber, D.L. Synthesis, properties, and applications of iron nanoparticles. Small 2005, 1, 482-501. [CrossRef] [PubMed]

70. Bomatí-Miguel, O.; Morales, M.P.; Tartaj, P.; Ruiz-Cabello, J.; Bonville, P.; Santos, M.; Zhao, X.; Veintemillas-Verdaguer, $\mathrm{S}$. Fe-based nanoparticulate metallic alloys as contrast agents for magnetic resonance imaging. Biomaterials 2005, 26, 5695-5703. [CrossRef] [PubMed]

71. Lee, C.M.; Jeong, H.J.; Kim, E.M.; Kim, D.W.; Lim, S.T.; Kim, H.T.; Park, I.K.; Jeong, Y.Y.; Kim, J.W.; Sohn, M.H. Superparamagnetic iron oxide nanoparticles as a dual imaging probe for targeting hepatocytes in vivo. Magn. Reson. Med. Off. J. Int. Soc. Magn. Reson. Med. 2009, 62, 1440-1446. [CrossRef]

72. Yean, S.; Cong, L.; Yavuz, C.T.; Mayo, J.; Yu, W.; Kan, A.; Colvin, V.; Tomson, M. Effect of magnetite particle size on adsorption and desorption of arsenite and arsenate. J. Mater. Res. 2005, 20, 3255-3264. [CrossRef]

73. Yokoyama, T.; Masuda, H.; Suzuki, M.; Ehara, K.; Nogi, K.; Fuji, M.; Fukui, T.; Suzuki, H.; Tatami, J.; Hayashi, K. Basic properties and measuring methods of nanoparticles. In Nanoparticle Technology Handbook; Elsevier: Amsterdam, The Netherlands, 2008; pp. 3-48.

74. Wiekhorst, F.; Seliger, C.; Jurgons, R.; Steinhoff, U.; Eberbeck, D.; Trahms, L.; Alexiou, C. Quantification of magnetic nanoparticles by magnetorelaxometry and comparison to histology after magnetic drug targeting. J. Nanosci. Nanotechnol. 2006, 6, 3222-3225. [CrossRef]

75. Namdeo, M.; Saxena, S.; Tankhiwale, R.; Bajpai, M.; Mohan, Y.; Bajpai, S. Magnetic nanoparticles for drug delivery applications. J. Nanosci. Nanotechnol. 2008, 8, 3247-3271. [CrossRef]

76. Lu, A.H.; Salabas, E.E.; Schüth, F. Magnetic nanoparticles: Synthesis, protection, functionalization, and application. Angew. Chem. Int. Ed. 2007, 46, 1222-1244. [CrossRef]

77. Arruebo, M.; Galán, M.; Navascués, N.; Téllez, C.; Marquina, C.; Ibarra, M.R.; Santamaría, J. Development of magnetic nanostructured silica-based materials as potential vectors for drug-delivery applications. Chem. Mater. 2006, 18, 1911-1919. [CrossRef]

78. Rosengart, A.J.; Kaminski, M.D.; Chen, H.; Caviness, P.L.; Ebner, A.D.; Ritter, J.A. Magnetizable implants and functionalized magnetic carriers: A novel approach for noninvasive yet targeted drug delivery. J. Magn. Magn. Mater. 2005, 293, 633-638. [CrossRef]

79. Wang, L.; Zhou, W.; Zhong, Y.; Huo, Y.; Fan, P.; Zhan, S.; Xiao, J.; Jin, X.; Gou, S.; Yin, T. Overexpression of G protein-coupled receptor GPR87 promotes pancreatic cancer aggressiveness and activates NF- $\mathrm{KB}$ signaling pathway. Mol. Cancer 2017, 16, 61. [CrossRef] [PubMed]

80. Blake, A.; Dragan, M.; Tirona, R.G.; Hardy, D.B.; Brackstone, M.; Tuck, A.B.; Babwah, A.V.; Bhattacharya, M. G protein-coupled KISS1 receptor is overexpressed in triple negative breast cancer and promotes drug resistance. Sci. Rep. 2017, 7, 46525. [CrossRef] [PubMed]

81. Boyd, B. Drug Delivery Report Autumn/Winter; PharmaVentures Ltd.: Oxford, UK, 2005.

82. Tomalia, D.A. Birth of a new macromolecular architecture: Dendrimers as quantized building blocks for nanoscale synthetic polymer chemistry. Prog. Polym. Sci. 2005, 30, 294-324. [CrossRef] 
83. Vo, T.N.; Kasper, F.K.; Mikos, A.G. Strategies for controlled delivery of growth factors and cells for bone regeneration. Adv. Drug Deliv. Rev. 2012, 64, 1292-1309. [CrossRef] [PubMed]

84. Zhang, J.; Saltzman, M. Engineering biodegradable nanoparticles for drug and gene delivery. Chem. Eng. Prog. 2013, 109, 25. [PubMed]

85. Kohane, D.S. Microparticles and nanoparticles for drug delivery. Biotechnol. Bioeng. 2007, 96, $203-209$. [CrossRef] [PubMed]

86. D. Friedman, A.; E. Claypool, S.; Liu, R. The smart targeting of nanoparticles. Curr. Pharm. Des. 2013, 19, 6315-6329. [CrossRef]

87. Osakwe, O.; Rizvi, S.A. Social Aspects of Drug Discovery, Development and Commercialization; Academic Press: San Diego, CA, USA, 2016.

88. Onoue, S.; Yamada, S.; Chan, H.-K. Nanodrugs: Pharmacokinetics and safety. Int. J. Nanomed. 2014, 9, 1025. [CrossRef]

89. Kudr, J.; Haddad, Y.; Richtera, L.; Heger, Z.; Cernak, M.; Adam, V.; Zitka, O. Magnetic nanoparticles: From design and synthesis to real world applications. Nanomaterials 2017, 7, 243. [CrossRef]

90. Sun, C.; Lee, J.S.; Zhang, M. Magnetic nanoparticles in MR imaging and drug delivery. Adv. Drug Deliv. Rev. 2008, 60, 1252-1265. [CrossRef] [PubMed]

91. Skalickova, S.; Nejdl, L.; Kudr, J.; Ruttkay-Nedecky, B.; Jimenez Jimenez, A.; Kopel, P.; Kremplova, M.; Masarik, M.; Stiborova, M.; Eckschlager, T. Fluorescence characterization of gold modified liposomes with antisense N-myc DNA bound to the magnetisable particles with encapsulated anticancer drugs (doxorubicin, ellipticine and etoposide). Sensors 2016, 16, 290. [CrossRef] [PubMed]

92. Mahmoudi, M.; Sant, S.; Wang, B.; Laurent, S.; Sen, T. Superparamagnetic iron oxide nanoparticles (SPIONs): Development, surface modification and applications in chemotherapy. Adv. Drug Deliv. Rev. 2011, 63, $24-46$. [CrossRef] [PubMed]

93. Gupta, A.K.; Gupta, M. Synthesis and surface engineering of iron oxide nanoparticles for biomedical applications. Biomaterials 2005, 26, 3995-4021. [CrossRef] [PubMed]

94. McCarthy, J.R.; Weissleder, R. Multifunctional magnetic nanoparticles for targeted imaging and therapy. Adv. Drug Deliv. Rev. 2008, 60, 1241-1251. [CrossRef] [PubMed]

95. Heger, Z.; Zitka, J.; Cernei, N.; Krizkova, S.; Sztalmachova, M.; Kopel, P.; Masarik, M.; Hodek, P.; Zitka, O.; Adam, V. 3D-printed biosensor with poly (dimethylsiloxane) reservoir for magnetic separation and quantum dots-based immunolabeling of metallothionein. Electrophoresis 2015, 36, 1256-1264. [CrossRef] [PubMed]

96. Zitka, O.; Cernei, N.; Heger, Z.; Matousek, M.; Kopel, P.; Kynicky, J.; Masarik, M.; Kizek, R.; Adam, V. Microfluidic chip coupled with modified paramagnetic particles for sarcosine isolation in urine. Electrophoresis 2013, 34, 2639-2647. [CrossRef] [PubMed]

97. Pileni, M.P. Magnetic fluids: Fabrication, magnetic properties, and organization of nanocrystals. Adv. Funct. Mater. 2001, 11, 323-336. [CrossRef]

98. Tartaj, P.; del Puerto Morales, M.; Veintemillas-Verdaguer, S.; González-Carreño, T.; Serna, C.J. The preparation of magnetic nanoparticles for applications in biomedicine. J. Phys. D Appl. Phys. 2003, 36, R182. [CrossRef]

99. Sun, Y.-k.; Ma, M.; Zhang, Y.; Gu, N. Synthesis of nanometer-size maghemite particles from magnetite. Colloids Surf. A Physicochem. Eng. Asp. 2004, 245, 15-19. [CrossRef]

100. Ma, M.; Zhang, Y.; Yu, W.; Shen, H.-Y.; Zhang, H.-Q.; Gu, N. Preparation and characterization of magnetite nanoparticles coated by amino silane. Colloids Surf. A Physicochem. Eng. Asp. 2003, 212, 219-226. [CrossRef]

101. Park, J.; An, K.; Hwang, Y.; Park, J.-G.; Noh, H.-J.; Kim, J.-Y.; Park, J.-H.; Hwang, N.-M.; Hyeon, T. Ultra-large-scale syntheses of monodisperse nanocrystals. Nat. Mater. 2004, 3, 891. [CrossRef] [PubMed]

102. Zitka, O.; Krizkova, S.; Krejcova, L.; Hynek, D.; Gumulec, J.; Masarik, M.; Sochor, J.; Adam, V.; Hubalek, J.; Trnkova, L. Microfluidic tool based on the antibody-modified paramagnetic particles for detection of 8-hydroxy-2'-deoxyguanosine in urine of prostate cancer patients. Electrophoresis 2011, 32, 3207-3220. [CrossRef] [PubMed]

103. Kang, B.J.; Jeun, M.; Jang, G.H.; Song, S.H.; Jeong, I.G.; Kim, C.-S.; Searson, P.C.; Lee, K.H. Diagnosis of prostate cancer via nanotechnological approach. Int. J. Nanomed. 2015, 10, 6555.

104. Patel, D.; Moon, J.Y.; Chang, Y.; Kim, T.J.; Lee, G.H. Poly (D, L-lactide-co-glycolide) coated superparamagnetic iron oxide nanoparticles: Synthesis, characterization and in vivo study as MRI contrast agent. Colloids Surf. A Physicochem. Eng. Asp. 2008, 313, 91-94. [CrossRef] 
105. Prabha, G.; Raj, V. Formation and characterization of $\beta$-cyclodextrin $(\beta$-CD)-polyethyleneglycol (PEG)-polyethyleneimine (PEI) coated $\mathrm{Fe}_{3} \mathrm{O}_{4}$ nanoparticles for loading and releasing 5-Fluorouracil drug. Biomed. Pharmacother. 2016, 80, 173-182. [CrossRef] [PubMed]

106. Karimzadeh, I.; Aghazadeh, M.; Doroudi, T.; Ganjali, M.R.; Kolivand, P.H. Superparamagnetic iron oxide $\left(\mathrm{Fe}_{3} \mathrm{O}_{4}\right)$ nanoparticles coated with PEG/PEI for biomedical applications: A facile and scalable preparation route based on the cathodic electrochemical deposition method. Adv. Phys. Chem. 2017, 2017. [CrossRef]

107. Li, J.; Zheng, L.; Cai, H.; Sun, W.; Shen, M.; Zhang, G.; Shi, X. Polyethyleneimine-mediated synthesis of folic acid-targeted iron oxide nanoparticles for in vivo tumor MR imaging. Biomaterials 2013, 34, 8382-8392. [CrossRef]

108. Rodrigo, M.A.M.; Krejcova, L.; Kudr, J.; Cernei, N.; Kopel, P.; Richtera, L.; Moulick, A.; Hynek, D.; Adam, V.; Stiborova, M. Fully automated two-step assay for detection of metallothionein through magnetic isolation using functionalized $\gamma-\mathrm{Fe}_{2} \mathrm{O}_{3}$ particles. J. Chromatogr. B 2016, 1039, 17-27. [CrossRef]

109. Jian, P.; Fen, Z.; Lu, L.; Liang, T.; Li, Y.; Wei, C.; Hui, L.; TANG, J.-b.; WU, L.-x. Preparation and characterization of PEG-PEI/Fe $\mathrm{F}_{3} \mathrm{O}_{4}$ nano-magnetic fluid by co-precipitation method. Trans. Nonferrous Metals Soc. China 2008, 18, 393-398.

110. Lee, J.-H.; Huh, Y.-M.; Jun, Y.-W.; Seo, J.-W.; Jang, J.-T.; Song, H.-T.; Kim, S.; Cho, E.-J.; Yoon, H.-G.; Suh, J.-S. Artificially engineered magnetic nanoparticles for ultra-sensitive molecular imaging. Nat. Med. 2007, 13, 95. [CrossRef] [PubMed]

111. Kim, J.; Lee, N.; Hyeon, T. Recent development of nanoparticles for molecular imaging. Philos. Trans. R. Soc. A Math. Phys. Eng. Sci. 2017, 375, 20170022. [CrossRef]

112. Dutz, S.; Clement, J.H.; Eberbeck, D.; Gelbrich, T.; Hergt, R.; Müller, R.; Wotschadlo, J.; Zeisberger, M. Ferrofluids of magnetic multicore nanoparticles for biomedical applications. J. Magn. Magn. Mater. 2009, 321, 1501-1504. [CrossRef]

113. Seo, W.S.; Lee, J.H.; Sun, X.; Suzuki, Y.; Mann, D.; Liu, Z.; Terashima, M.; Yang, P.C.; McConnell, M.V.; Nishimura, D.G. FeCo/graphitic-shell nanocrystals as advanced magnetic-resonance-imaging and near-infrared agents. Nat. Mater. 2006, 5, 971. [CrossRef] [PubMed]

114. Kainz, Q.M.; Fernandes, S.; Eichenseer, C.M.; Besostri, F.; Körner, H.; Müller, R.; Reiser, O. Synthesis of functionalized, dispersible carbon-coated cobalt nanoparticles for potential biomedical applications. Faraday Discuss. 2015, 175, 27-40. [CrossRef] [PubMed]

115. Stevenson, J.; Rutnakornpituk, M.; Vadala, M.; Esker, A.; Charles, S.; Wells, S.; Dailey, J.; Riffle, J. Magnetic cobalt dispersions in poly (dimethylsiloxane) fluids. J. Magn. Magn. Mater. 2001, 225, 47-58. [CrossRef]

116. Rutnakornpituk, M.; Baranauskas, V.; Riffle, J.; Connolly, J.; St Pierre, T.; Dailey, J. Polysiloxane fluid dispersions of cobalt nanoparticles in silica spheres for use in ophthalmic applications. Eur. Cells Mater 2002, 3, 102-105.

117. Osorio-Cantillo, C.; Santiago-Miranda, A.; Perales-Perez, O.; Xin, Y. Size-and phase-controlled synthesis of cobalt nanoparticles for potential biomedical applications. J. Appl. Phys. 2012, 111, 07B324. [CrossRef]

118. Joubert, J. Magnetic micro composites as vectors for bioactive agents: The state of art. Anales de Quimica 1997, 93, 70-76.

119. Grasset, F.; Mornet, S.; Demourgues, A.; Portier, J.; Bonnet, J.; Vekris, A.; Duguet, E. Synthesis, magnetic properties, surface modification and cytotoxicity evaluation of $\mathrm{Y}_{3} \mathrm{Fe}_{5-\mathrm{x}} \mathrm{Al}_{\mathrm{x}} \mathrm{O}_{12}(0 \leq \mathrm{x} \leq 2)$ garnet submicron particles for biomedical applications. J. Magn. Magn. Mater. 2001, 234, 409-418. [CrossRef]

120. Rinaldi-Montes, N.; Gorria, P.; Martínez-Blanco, D.; Amghouz, Z.; Fuertes, A.B.; Barquín, L.F.; de Pedro, I.; Olivi, L.; Blanco, J.A. Unravelling the onset of the exchange bias effect in $\mathrm{Ni}$ (core)@ $\mathrm{NiO}$ (shell) nanoparticles embedded in a mesoporous carbon matrix. J. Mater. Chem. C 2015, 3, 5674-5682. [CrossRef]

121. Zhou, W.; Zheng, K.; He, L.; Wang, R.; Guo, L.; Chen, C.; Han, X.; Zhang, Z. Ni/Ni3C core-shell nanochains and its magnetic properties: One-step synthesis at low temperature. Nano Lett. 2008, 8, 1147-1152. [CrossRef] [PubMed]

122. Rahal, H.; Awad, R.; Abdel-Gaber, A.; Bakeer, D. Synthesis, characterization, and magnetic properties of pure and EDTA-capped $\mathrm{NiO}$ nanosized particles. J. Nanomater. 2017, 2017. [CrossRef]

(C) 2019 by the authors. Licensee MDPI, Basel, Switzerland. This article is an open access article distributed under the terms and conditions of the Creative Commons Attribution (CC BY) license (http://creativecommons.org/licenses/by/4.0/). 